\title{
Additional notes on systematic of Neotropical Dissomphalus Ashmead (Hymenoptera, Bethylidae)
}

\author{
Celso Oliveira Azevedo ${ }^{1}$
}

\begin{abstract}
Diagnosis and genitalia description and illustration of Dissomphalus bicavatus Evans, 1979; D. bispinulatus Evans, 1969; D. brasiliensis Kieffer, 1910;D. caviclypeus Evans, 1969; D. cornutus Evans 1964; D. dumosus, Evans, 1966; D. fungosus Evans, 1979; D. gilvipes Evans, 1979; D. incomptus Evans, 1964; D. infissus Evans, 1969; D. mendicus Evans, 1969; D. microstictus Evans, 1969; D. mirabilis Evans, 1966; D. nanellus Evans, 1969; D. napo Evans, 1979; D. plaumanni Evans, 1964; D. punctatus (Kieffer, 1910); D. puteolus Evans, 1969; D. rufipalpis Kieffer, $1910 ;$ D. xanthopus Ashmead, 1893 are provided. Female of D. mirabilis is first described. Five synonymies are proposed: $D$. connubialis Evans, 1966 of $D$. brasiliensis, D. montanus Kieffer, 1910 of D. punctatus, D. obliquus Evans, 1979 of D. rufipalpis, D. teren Evans, 1969 of D. cornutus and D. hastatus Evans, 1979 of D. bispinulatus. D. microtuberculatus sp.n. from Northern Argentina is described and illustrated.
\end{abstract}

KEY WORDS. Hymenoptera, Bethylidae, Dissomphalus, Neotropical, systematic

The Neotropical species of Dissomphalus Ashmead, 1893 with median tergal processes were revised and organized in 13 species groups by AZEVEDO (1999), who described 40 new species. This paper intends to be a continuation of the understanding of the Neotropical Dissomphalus. Here, the diagnosis and genitalia descriptions of some species of Dissomphalus from Neotropical region are presented, but some specimens from USA were included.

The material examined was provided by the following institutions: AMNH - American Museum of Natural History, USA (J.M. Carpenter \& E. Quinter); BMNH - The Natural History Museum, England (T. Huddleston); CASC - California Academy of Sciences, USA (W. Pulawsky); CNCI - Canadian National Collection of Insects, Canada (J.T. Huber); CUIC - Cornell University, USA (E.R. Hoebecke); DCBU - Universidade Federal de São Carlos, Brazil (A.M. PenteadoDias); DZUP - Universidade Federal do Paraná, Brazil (K. Zanol); EMUS - Utah State University, USA (W.J. Hanson); FIML - Fundación y Instituto Miguel Lillo, Argentina (A. Willink); FIOC-Fundação Instituto Oswaldo Cruz do Rio de Janeiro, Brazil (S.J. Oliveira); FSCA - Florida State Collection of Arthropods, USA (L. Stange \& J. Wiley); IBGE - Instituto Brasileiro de Geografia e Estatística, Brasília, Brazil (B. Dias); INPA - Instituto Nacional de Pesquisas da Amazônia, Brazil (C. Magalhães); LACM - Los Angeles County Museum of Natural History, USA (R.R.

1) Departamento de Biologia, Universidade Federal do Espírito Santo. Avenida Marechal Campos 1468, Maruipe, 29040-090 Vitória, Espírito Santo, Brasil.

E-mail: cazevedo@npd.ufes.br 
Snelling); MCZH - Museum of Comparative Zoology, USA (S. Cover \& P.D. Perkins); MNRJ - Museu Nacional do Rio de Janeiro, Brazil (R. Tibana); MPEG -Museu Paraense Emílio Goeldi, Brazil (A. Harada); MZSP - Museu de Zoologia de São Paulo, Brazil (C.R.F. Brandão); OSUC - Ohio State University, USA (N. Johnson); PMAE - Provincial Museum of Alberta, Canada (A.T. Finnamore); SEAN - Museo de Entomologia de Nicaragua (J.M. Maes); UCDC - Bohart Museum of Entomology, USA (S.L. Heydon); UCRC-Entomological Teaching and Research Collection, USA (S.V. Triapitsyn); UFES - Universidade Federal do Espírito Santo, Brazil (C.O. Azevedo); USNM - National Museum of Natural History, USA (K.V. Krombein); ZMHB - Zoologisches Museum der HumboldtUniversität, Berlin, Germany (A. Kleine-Möllhof \& F. Koch).

Main measurements and indices used in this study are as follow: (LH) length of head, measured in frontal view, from the vertex crest to the median apical margin of the clypeus; (WH) width of head, measured in frontal view, its maximum width including the eyes; (WF) width of frons, measured in frontal view, its minimum width, usually about the bottom of the eyes; (HE) height of eye, measured in lateral view, its maximum height (length); (OOL) ocello-ocular line, measured in laterodorsal view, the shortest distance from the eye top to the posterior ocellus; (WOT) width of the ocellar triangle, measured in frontal view, the maximum width, including the ocelli; (DAO) diameter of anterior ocellus, measured in frontal view; distance of the ocellar triangle to vertex: measured in dorsal view, the distance from posterior ocellus to vertex crest; (VOL) vertex-ocular line, measured in lateral view, the distance from the eye top to vertex crest; (LFW) length of forewing.

The nomenclature of integument sculpture follows HARRIS (1979). Terminology generally follows EVANS (1964) and AZEVEDo (1999).

\section{Dissomphalus bicavatus Evans, 1979}

Fig. 1

Diagnosis, male. Mandible bidentate. Clypeus subtrapezoidal. Frons somewhat strongly coriarious, with large and shallow punctures, separated by $1-2 \mathrm{X}$ their diameters. Vertex nearly straight, with a very small median depression. Pronotal disc very short. Tergite II with a pair of latero-anterior depressions, broadly separated, distant each other $3 \mathrm{X}$ their diameters, distant from the anterior margin $0.25 \mathrm{X}$ their diameters, reaching the lateral margin of the tergite in dorsal view, depression ovoid, very large, $1.0 \mathrm{X}$ length of the tergite, border with short hairs directed backward, being the median outer hairs denser and longer, lateral inner face of the depression with a pit with high border.

Genitalia (Fig. 1). Paramere with apex oblique, slightly concave, dorsal corner much produced, base of ventral margin straight, dorsal margin evenly little developed; volsella with cuspis slightly dilated apically, base of the volsella with a conspicuous sharpened tooth, arched and as long as the digitus; aedeagus with ventral ramus longer than the dorsal body, apical half somewhat convergent, apex bidentate, inner tooth slightly larger, ramus with subvertical surfaces, widened basally; dorsal body of the aedeagus very elongated, with three pairs of apical lobes, 

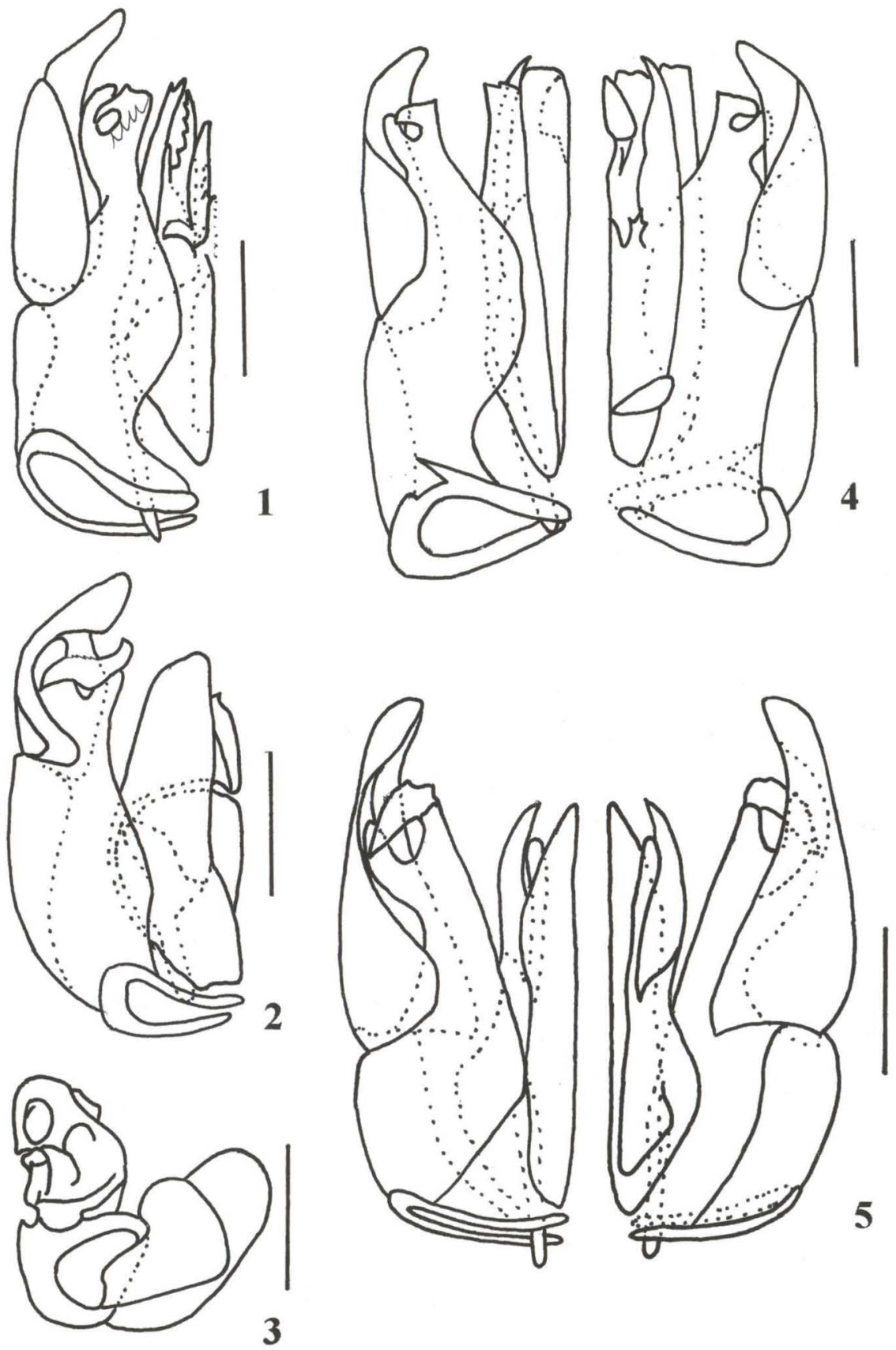

Figs 1-5. (1) D. bicavatus, genitalia, ventral; (2-3) D. bispinulatus, genitalia: (2) ventral; (3) posterior; (4-5) genitalia, ventral on left, dorsal on right: (4) D. brasiliensis; (5) D. caviclypeus. Scale bar $=115 \mu \mathrm{m}$. 
the ventral pair smaller, laminar, horizontal, wide basally and narrowing to the sharpened apex, the inner pair somewhat membranous, densely hairy inside, with rounded apex, transversal section semicircular, with inner side straight, the outer pair large, laminar, surfaces dorsal and projected inward, outer margin with 6 teeth sharpened progressively smallest in the apex, inner margin with a projection in the same level of outer basal tooth, with blunt apex and reaching the level of the outer third tooth, apex of the inner margin sinuous, dorsal body of the aedeagus with the dorsal base with a sharpened median tooth and with a pair of lateral projections slightly larger than the tooth, evenly arched outward and with outer margin serrated; apodema extending beyond the elliptical genital ring.

Material examined. Venezuela, Zulia: El Tucuco (45 Km SW of Machiques), 1 male, 5-6.VI.1796, A.S. Menke \& D. Vincent leg. (USNM, paratype).

Distribution. Venezuela.

\section{Dissomphalus bispinulatus Evans, 1969}

Figs 2-3

Dissomphalus bispinulatus Evans, 1969: 13, 19-20. -Gordh \& Moczar 1990: 219.

D. hastatus Evans, 1979: 276, 277, 281-282. - Gordh \& Moczar 1990: 222. Syn.n.

Diagnosis, male. Mandible tridentate. Clypeus with a median tooth sharpened very large, half length of the clypeus. Eye glabrous with the inner orbit not invaginated. Frons weakly coriarious, punctures very small, inconspicuous, deep, separated by $2 \mathrm{X}$ their diameters. Vertex slightly convex, corners not so rounded. Tergite II with a pair of large and shallow circular depressions, distant from the anterior margin of the tergite, $0.4 \mathrm{X}$ their diameters, and each other $0.3 \mathrm{X}$ their diameters, both depression occupying the half of the width of the tergite, each one with a small tubercle with short hairs. Hypopygium with straight posterior margin.

Genitalia (Figs 2, 3). Paramere with apex produced, slightly concave and much arched inward; volsella with digitus with a large basal projection; aedeagus with ventral ramus much longer than the dorsal body, wide with apex rounded and slightly less wide the base, tubular, parallel; dorsal body very short, and produced upward, with two pairs of apical lobes, the ventral pair small and arched upward, the dorsal pair stout, tubular with a small digitiform projection; apodema extending beyond the subquadratic genital ring.

Material examined. ARgEntinA, Salta: Orán (Abra Grande), 1 male, 1623.II.1967, Malaise trap, R. Golbach leg. (FIML, holotype). ECUADOR, Napo: Limoncocha (on Rio Napo), 2 males, 22.I.1974, Malaise trap, B.A. Drummond III leg. (FSCA, USNM paratypes of $D$. hastatus, junior synonym). New material: VenezUelA, Zulia: Los Angeles del Tucuco, 1 male, 15-16.IV.1981, A.S. Menke \& L. Hollenberg leg. (USNM); Tachira: Pregonero (Camp Siberia, Hospital, $1280 \mathrm{~m}, 2^{\text {nd }}$ forest road), 1 male, 10-31.VII.1989, F.X.T.; S. \& J. Peck (PMAE); Barinas: Quebradaseca (440m), 2 males, 13-27.VII.1986, B. Gill leg. (PMAE). BRITISH GUYANA: Kartago, 1 male, VII-VIII.1920, W.M. Wheeler leg. (MCZH). SURINAME: Foengoe Island (Voltzberg National Reserve), 1 male, 14.II.1972, F. Scott leg. (PMAE). EcUADOR, Napo: Limoncocha, 1 male, 15.VI.1976, S. \& J. Peck 
leg. (CNCI). Peru, Cuzco: Quillabamba, 2 males, 23-27.XII.1984, L. Huggert leg. (PMAE). BrazIL, Rondônia: (Br 364 km 119, Porto Velho-Cuiabá), 3 males, 6-16.III.1982, CDC light trap, J. Arias leg. (OSUC); São Paulo: Ibitinga (rubber-tree crop), 5 males, 15.VI.1988-21.II.1990, Möricke trap (UFES); São Carlos, 1 male 30.III.1993, M.T. Tavares leg. (UFES).

Variations. Median tooth of the clypeus smaller; punctures of frons more conspicuous; vertex slightly angulate; apex of the ventral ramus of the aedeagus slightly convex.

Remarks. This species has some uncommon characters in this genus as: dorsal body of the aedeagus very short (Fig. 2) and ventral ramus tubular (Fig. 2). It was known only from the type series of both junior and senior synonymies. Now, it is recorded for the first time to Venezuela, British Guyana, Suriname, Ecuador, Peru and Brazil.

Distribution. Venezuela, British Guyana, Suriname, Ecuador, Peru, Brazil (Rondônia, São Paulo) and Argentina (Salta).

\section{Dissomphalus brasiliensis Kieffer, 1910}

Fig. 4

Dissomphalus brasiliensis Kieffer, 1910a: 295. - 1914: 496, 502-503. - Evans, 1964: 46, 49-51. - Gordh \& Moczar, 1990: 219.

Dissomphalus connubialis Evans, 1966: 106-108. - Gordh \& Moczar, 1990: 220. Syn.n.

Diagnosis, male. Mandible bidentate. Clypeus trapezoidal. Frons somewhat strongly coriarious, punctures conspicuous. Vertex slightly convex, temple parallel. Tergite II with a pair of latero-anterior ovoid depressions, with apical part subangulate, inclined outward apically, not reaching neither the anterior nor the lateral margin of the tergite, slightly deep, each one with a dense short-haired tubercle in the anterior half of the depression, lateral margin hairy, anterior margin subangulate in posterior view, length of the depression $0.5 \mathrm{X}$ tergite, distant each other $2 \mathrm{X}$ their length. Hypopygium with slender stalk $1.5 \mathrm{X}$ the length of hypopygium, lateral teeth $5 \mathrm{X}$ smaller than the stalk, posterior margin slightly concave.

Genitalia (Fig. 4). Paramere arched inward only apically, apex much produced and thin, base of the ventral margin much developed, broadly blunt inside; volsella with short cuspis, not arched, inner margin of the digitus wholly serrated; ventral ramus of the aedeagus with same size of dorsal body, ramus latero-ventral to dorsal body, wide, laminar, with vertical surfaces, concave inside, apex wide and blunt with a small and rounded tooth, outer and inner margins parallel; dorsal body of the aedeagus with three pairs of apical lobes of about the same size, the inner pair elongated vesicle-shaped with rounded apex, the median pair somewhat membranous, laminar, ventral, wide, being the inner densely hairy, the outer pair with a apical projection inclined downward with strongly serrated margin; all lobes with vertical surfaces; dorsum of the base of the aedeagus with a sharpened median tooth with a pair of basal expansion and paralleled by a tridentate projection $2 \mathrm{X}$ longer than it, the median tooth of the projection large; base of the aedeagus with a pair of expansion with a median invagination in dorsal side; apodema not extending beyond the sub-rectangular genital ring. 
Female. Head: weakly coriarious, punctures not so large and not so shallow separated by $0.2-1,5 \mathrm{X}$ their diameters, absent in a longitudinal median band. Clypeus trapezoidal, invaginated apically, median carina very high, angled before the apical margin. Vertex concave, sides of head parallel and convex. Gaster peciolate.

Material examined. BrAZIL, 1 male, Hansel type $\mathrm{n}^{\circ} 164$, (MCZH, holotype of D. brasiliensis); Santa Catarina: Seara (Nova Teutônia, $27^{\circ} 11^{\prime} \mathrm{S}, 52^{\circ} 23^{\prime} \mathrm{W}$, 300-500m), 15 males, 5 females, IV.1950-IX.1966, F. Plaumann leg. (UCRC, MCZH, MZSP holotype, paratypes, alotype of D. connubialis). New material: BrazIL, Pernambuco: Caruaru, 6 males, IV.1972, M. Alvarenga leg. (PMAE); Distrito Federal: Brasília (Reserva Ecológica do IBGE, 1555'58"S, 4751'02"W, border of forest), 1 male, 23-30.XII.1982, window trap, J. Dalmáceo leg. (IBGE); Espírito Santo: Linhares, 1 male, XI.1962, F.M. Oliveira leg. (PMAE); Rio de Janeiro: Ilha Jaguanum, 4 males, 3.IX-5.X.1982, D. Hunt leg. (UCDC); Silva Jardim, 1 male, VIII.1974, F.M. Oliveira leg. (CNCI); Rio de Janeiro, 1 male, I. 1972, M. Alvarenga leg. (PMAE); São Paulo: Serra da Bocaina, 1 male, 13-17.I.1969 (MCZH); Parequera-açu, 1 male, 14.V.1986, Möricke trap (UFES); São Paulo, (Jabaquara, Oriental Garden), 1 male, 28.II-9.III.1990, Amarante leg. (MZSP); São Carlos (Parque Ecológico, cerrado), 1 male, 26.XI.1986, sweeping; F. Passos leg. (DCBU); São Carlos (Fazenda Canchim, forest), 1 male, 2.IX.1988, L.A. Joaquim leg. (DCBU); Ubatuba (Estação Experimental do Instituto Agronômico, forest, Möricke trap), 2 males, N.F. Cristo leg. (DCBU); Paraná: 11.VIII.198628.IV.1988, 31 males, Jundiaí do Sul (Monte Verde Farm); 24 males, Ponta Grossa (Vila Velha, Iapar Reserve, Br 376); 1 male, Colombo (Embrapa, Br 476, km 20); 4 males Telêmaco Borba (Samuel Klabin Reserve); 1 male, Guarapuava (Estação Águas Santa Clara); 1 male Fênix (ITCF Station Reserve), Malaise trap, Levantamento Profaupar (all DZUP); Curitiba, 1 male, 20-31.I.1969, L. Stange leg. (MCZH); Santa Catarina: Piçarras (forest), 1 male, I.1989, suspensa trap, Pentea-

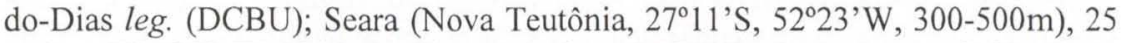
males, IV.1950-IX.1966, F. Plaumann leg. (MCZH). ArgentinA, Salta: Orán (Abra Grande), 2 males, 18.IV-5.V.1969, C. Porter leg. (MCZH); Pocitos, 1 male, XII.1971, M. Fritz leg. (MCZH); Misiones: Iguazu, 1 male, 4-10.X.1927, R.C. \& E.M. Shannon leg. (USNM); Dos de Mayo, 1 male, XII.1973, Fritz leg. (MCZH). URUGUAY, Tacuarembo: (40 km NW Tacuarembo), 1 male, 2-9.II.1963, J.K. Bouseman leg. (AMNH).

Variations. Posterior margin of hypopygium slightly more concave; specimens from Pernambuco (Brazil) with base of ventral margin of the paramere straight, apex of ventral ramus of aedeagus strongly concave, and the paralleled basal expansion of the dorsal base of aedeagus bidentate.

Remarks. This species was known only from type-localities of both junior and senior synonymies and it is recorded for the first time to Argentina and Uruguay. The paramere is usually more developed dorsally, but the ventral margin is specially developed.

Distribution. Brazil (Distrito Federal, Rio de Janeiro, São Paulo, Paraná, Santa Catarina), Argentina (Salta, Misiones) and Uruguay. 


\section{Dissomphalus caviclypeus Evans, 1969}

Fig. 5

Diagnosis, male. Mandible tridentate. Clypeus short-tridentate, with two low median carinae, divergent apically, arched outward medially, with rounded top, concave in profile, space between the carinae with a cavity. Frons coriarious, with small punctures. Vertex slightly convex. Pronotal disc with a transversal anterior carina well-defined and dentate. Tergite II with a pair of microtubercles in the middle of the length of the tergite and slightly closer to the lateral margin than median line, with an only long and hair directed backward, tergite with some short lateral hairs. Hypopygium with stalk $1.4 \mathrm{X}$ the length of hypopygium, lateral tooth $4 \mathrm{X}$ smaller than the stalk, posterior margin straight and narrow, lateral margins very convergent.

Genitalia (Fig. 5). Paramere $2 X$ longer than the basiparamere, dorsal margin much developed, with basal corner angulate, apex narrow and rounded, not arched inward; volsella with thin digitus, not serrated, with apex slightly dilated, cuspis with outer margin widened apically; aedeagus with ventral ramus longer than the dorsal body, apical half inclined downward, laminar, surfaces horizontal, outer margin folded upward slightly before the apex, where the ramus is wider, apex sharpened and convergent; dorsal body of the aedeagus with two pairs of apical lobes, the inner pair somewhat membranous, smaller than the outer, evenly narrow, with irregular surfaces, slightly divergent, the outer pair laminar, vertical, concave and densely hairy inside; apodema with dilated apex, extending beyond the elliptical genital ring.

Material examined. Dominica: (1.5 mi. N. Point Cassé, 1200'), 1 male, 12-25.II.1965 (USNM, paratype).

Remarks. The tergal processes of this species remember those of $D$. politus Ashmead, 1894, but with reduced size.

Distribution. Dominica.

\section{Dissomphalus cornutus Evans, 1964}

Dissomphalus cornutus Evans, 1964: 13, 18-19. - Gordh \& Moczar, 1990: 226.

Dissomphalus teren Evans, 1969a: 46, 56-58. - Gordh \& Moczar, 1990: 221. Syn.n.

Diagnosis, male. Mandible tetradentate. Clypeus tridentate, with a median carina divided longitudinally, forming an inner lozengy concavity, such carina is concave and high in profile. Malar space broad. Frons very convex, coriarious, punctures inconspicuous, separated by 1.5-2.0 X their diameters. Vertex evenly convex, with rounded corners, head very developed behind the eye, distance from the eye top to vertex crest $0.75 \mathrm{X}$ HE. Gena without subgenal and with carina post-genal incomplete medially. Notauli straight, thin and shallow, only in the anterior half of the mesoscutum; parapsidal furrows complete. Tergite II with a pair of thin tuft of long hairs directed backward, as long as half distance between the tufts, hairs given risen directly from the surface of the tergite, without pits or tubercles, the tufts in the middle of the anterior half of the tergite and slightly more distant each other than to the lateral margin of the tergite in dorsal view. Hypopygium with a stalk $0.75 \mathrm{X}$ the length of hypopygium, posterior margin concave, corners angulate. 
Genitalia. Paramere much arched inward, apex with a long and thin projection, inner face with some long hairs directed inward, base developed; volsella with cuspis much produced internally and digitus thin basally and wide apically; aedeagus with ventral ramus as long as dorsal body, evenly wide with blunt apex, slightly sinuous, dorsal body with the base very wide and apex narrow, forming digitiform structure; apodema not extending beyond the elliptical genital ring.

Material examined. Brazil, Santa Catarina: Seara (Nova Teutônia), 5 males, 19-28.II.1945, F. Plaumann leg. (BMNH, MCZH paratypes); Seara (Nova Teutônia), 1 male, X.1965, F. Plaumann leg. (MCZH). Argentina, Tucumán: Horco Molle (San Xavier Mts), 1 male, 3-11.VI.1966; L. Stange leg. (FIML, holotype, D. teren, junior synonym). New material: ECUADOR, Pichincha: Tinalandia (16km SE Santo Domingo, 600m), 1 male, VI-VIII.1985, S. \& J. Peck leg. (PMAE); Napo: Tena, 1 male, 15.II.1986, sweep, A.T. Finnamore leg. (PMAE). BRAZIL, São Paulo: Bauru (Estação Ecológica, cerrado), 1 male, 12.I.1994, suspensa trap, S.S. Ruiz leg. (UFES); Santa Catarina: Sera (Nova Teutônia), 1 male, 30.X-XI.1965, F. Plaumann leg. (MCZH, UCRC); Paraná: Ponta Grossa (Vila Velha, Reserva Iapar Br 376), 1 male, 1.II.1988, Levantamento Profaupar (DZUP).

Variations. The process of the clypeus varies in size (Evans 1964), can be very large, as a horn; the position of the vertex of the process varies in relation to the apical margin and the width of the concavity of the process; the lower region of the ocelli more deeply invaginated; pronotal disc strongly coriarious; texture of the body of one specimen is very strong; specimens from Ecuador and Argentina with apex of the paramere slightly thinner.

Remarks. This species has some uncommon characters as: notauli weak and reduced to the anterior half of the mesoscutum, median carina of the clypeus divided longitudinally (EVANS 1964), forming an inner concavity, malar space uncommonly broad, absence of the subgenal carina and presence of incomplete post-genal carina. Evans (1969a) described $D$. teren when he also discussed some characters as reduced notauli, presence of tetradentate mandible, but he did not established any relation between both species. I analyzed several paratypes of $D$. cornutus and the holotype of $D$ teren, when I observed that both species have all characters above cited and have genitalia very similar.

Distribution. Ecuador, Brazil (São Paulo, Paraná, Santa Catarina), Argentina (Tucumán).

\section{Dissomphalus dumosus Evans, 1966}

Fig. 6

Diagnosis. Male: mandible tridentate. Clypeus trapezoidal, developed, with rounded corners. Frons coriarious, densely punctated, with punctures shallow, large, dense, separated by 0.1-0.8 X their diameters. Vertex shortly straight, with corners broadly rounded. Head much developed behind the eyes. Tergite II with a pair of rounded depressions, distant each other $4.3 \mathrm{X}$ their diameters, nearly reaching the lateral and anterior margins of the tergite, each one with a small median hairy tubercle, lateral margin of the depression with many long hairs directed backward. 

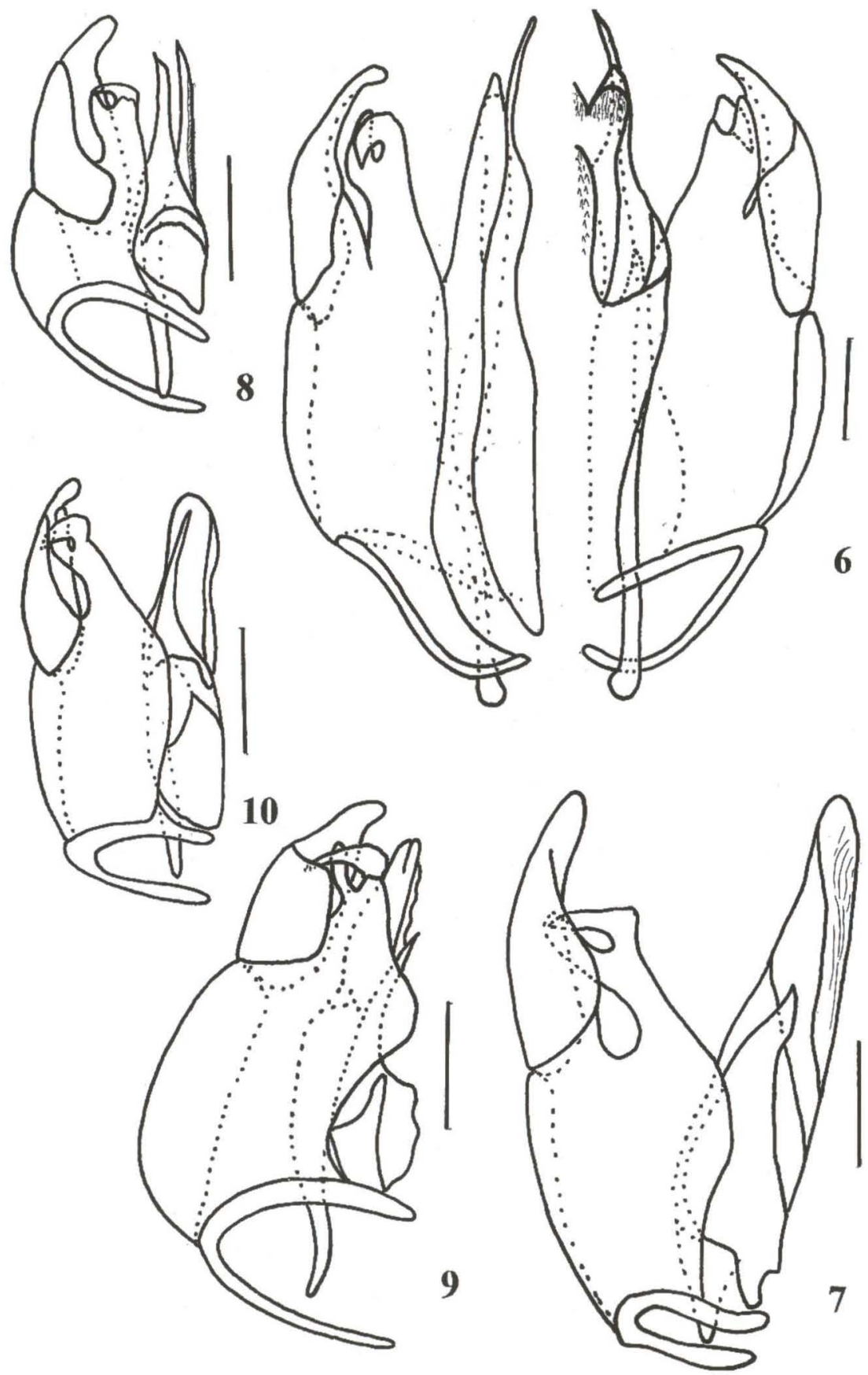

Figs 6-10. (6) D. dumosus, genitalia, ventral on left, dorsal on right; (7-10) genitalia, ventral: (7) D. fungosus; (8) D. gilvipes; (9) $D$. infissus; (10) $D$. mendicus. Scale bar $=115 \mu \mathrm{m}$ ). 
Genitalia (Fig. 6). Paramere with apex oblique, slightly concave, with dorsal corner produced, dorsal margin slightly convex and much developed; volsella with digitus with wide apex and smooth upper margin; aedeagus with ventral ramus very long, extending the apex of the paramere, laminar, horizontal, inner margin straight basally, and concave in the apical half with a dilation medially, outer margin slightly convex, apex as filament, $0.33 \mathrm{X}$ the length of ramus; dorsal body with two pairs of apical lobes, the outer pair laminar, with vertical surfaces, with wide base, narrowing apically in lateral view, apex inclined downward, the inner lobe very wide, subcircular, with irregular upper margin, inner surface membranous, hairy and stout, base of body with a dorsal median filament, $0.66 \mathrm{X}$ the length of outer lobe paralleled by a pair of arched lateral teeth; base of the genitalia not expanded medially in the ventral side; basal ring much developed in the ventral side; apodema nearly reaching the ventral margin of the genital ring, with dilated and rounded apex.

Material examined. BRAzIL, Santa Catarina: Seara (Nova Teutônia), 2 males, X.1965, F. Plaumann leg. (MCZH, UCRC, paratype).

Remarks. This species has three peculiar characters, median lobe of the clypeus roundly trapezoidal and head much developed behind the eyes, as much as Pseudisobrachium pattern, and basal ring of the genitalia much developed ventrally.

Distribution. Brazil (Santa Catarina).

\section{Dissomphalus fungosus Evans, 1979}

Fig. 7

Diagnosis. Male: mandible tetradentate. Clypeus trapezoidal. Frons somewhat strongly coriarious, with punctures large, shallow, separated by 0.1-1.0 X their diameters (densely punctate). Vertex hardly concave, nearly straight, with corners somewhat rounded. Notauli very conspicuous. Pronotal disc very short. Scutellar groove widened medially. Propodeal disc with coarse reticulation (strongly striate). Tergite II with a pair of circular and deep lateral depressions, separated each other by $1.5 \mathrm{X}$ their diameters, with a tuft densely hairy, latero-anterior margin with hairs, depression distant from anterior margin of the tergite less than $0.5 \mathrm{X}$ their diameters. Hypopygium with a slender stalk, posterior margin straight.

Genitalia (Fig. 7). Paramere wide in lateral view, with rounded apex hardly arched inward; volsella with digitus with a basal digitiform projection; aedeagus with ventral ramus very short, $0.5 \mathrm{X}$ as long as the dorsal body, with base wide, narrowing evenly up to the apex, which is sharpened, ramus laminar, inner surface slightly concave, surfaces convergent ventrally in posterior view; dorsal body wide, with rounded apex, laminar, concave in the inner surface, and convergent dorsally in posterior view, inner surface hairy with a small apical tooth; apodema not extending beyond the subcircular genital ring.

Material examined. ECUADOR, Napo: Limoncocha (on Rio Napo), 1 male, 1.V.1974, Malaise trap, B.A. Drummond leg. (FSCA, paratype). New material: TrINIDAD \& ToBAgo, Trinidad: Asa Wright N.C., 1 male, 15.I.1981, G.E. Bohart leg. (EMUS); Cumoto, 1 male, W.S. Brooks leg. (MCZH). ECUADOR, Napo: Limoncocha, 1 male, 28.VI.1976, S. \& J. Peck leg. (PMAE); Mor. Santiago: Miazal 
(50km SE Macas, 300m), 1 male, 4-7.I.1993, M. \& J. Wasbauer leg. (UCDC). BRAZIL, Amazonas: Manaus (Reserva 1208 or 1112 or 1113), 4 males, 1.X.198513.III.1986, Malaise trap, B. Klein leg. (INPA); (Reserva Ducke), 1 male, 26.XI.1981, J.A. Rafael leg. (INPA); Pará: Altamira (km 18), 1 male, 23.IX.1985, interception trap, N. Degalier leg. (MPEG); Ourém (Pataventura, Fazenda Gavião Real), 1 male, 29.X.1990 (MPEG).

Remarks. This species was known only from Ecuador and type series, now it is recorded for the first time to Trinidad \& Tobago and Brazil.

Distribution. Trinidad \& Tobago, Ecuador and Brazil (Amazonas, Pará).

\section{Dissomphalus gilvipes Evans, 1979}

Fig. 8

Diagnosis. Male: mandible tetradentate. Clypeus wholly broadly projected toward, with three small teeth, median carina slightly high. Frons coriarious, punctures small, shallow, separated by 1-3 X their diameters. Vertex straight, with corners rounded. Temple small. Parapsidal furrows complete. Tergite II with a pair of subcircular depressions widely spaced, distant each other $2.5 \mathrm{X}$ their diameters, near the anterior margin of the tergite, and with a tubercle which gives rise a linear tuft of hairs, being the lateral one specially longer than the others, each depression occupying the anterior half of the tergite. Hypopygium with median stalk $1.5 \mathrm{X}$ the length of hypopygium, posterior margin straight, with a small rounded median projection.

Genitalia (Fig. 8). Paramere with a thin apical projection, arched inward, base of the dorsal margin much developed inward; aedeagus short, as high as base of volsella, ventral ramus as long as dorsal body, laminar, with vertical surfaces, with basal half wide and apical one narrow, apex blunt and oblique with outer corner sharpened; dorsal body with a pair of parallel lobe, narrowing apically in dorsal and lateral view, inner surface hairy, base of the dorsal body with denticles inside; base of the genitalia with a pair of laminar vertical and rectangular expansions, ventral margin not angulate; apodema not extending beyond the elliptical genital ring.

Material examined. ColomBiA, Valle: Central de Anchicaya $(30 \mathrm{~km}$ E. Buercuenta, tropical very wet forest, $560 \mathrm{~m}), 1$ male, 14-16.VII.1975, Malaise trap, R.C. Wilkerson leg. (FSCA, paratype). New material: ColomBIA, Valle: Central de Anchicaya (30 km E. Buenaventura, tropical very wet rain forest, $560 \mathrm{~m}$ ), 1 male, 26.VI.1975, R.C. Wilkerson leg. (FSCA). ECUADOR, Pichincha (Tinalandia, 16 km SE Santo Domingo, 500m), 13 males, VI-VII.1985, S. \& J. Peck leg. (PMAE); Tinalandia, 4 males, 14.VI.1976, S. \& J. Peck leg. (PMAE); (near Tinalandia, $1150 \mathrm{~m}$, lower manine moss forest, Malaise trap), 2 males, Brown \& Coole leg. (PMAE); (Rio Palenque, Reserve Station, 250m), 4 males, 5.V-25.VII.1985, S. \& J. Peck leg. (PMAE); Pastaza: (25 km N Puyo), 1 male, 4.VII.1976, S. \& J. Peck leg. (PMAE); Napo: Tena, 1 male, 20.II.1986, Malaise trap, A.T. Finnamore leg. (PMAE); Huahua Sumaco ( $\mathrm{km} 45$ on Hollin-Loreta road), 1 male, 15-22.XII.1989, Malaise trap, M. \& J. Wasbauer, H. Real leg. (PMAE). PERU, Junin: Satipo, 2 males 24.I.1984, L. Huggert (PMAE); Madre de Dios: Salvacion, 1 male, 24.VIII.1983, D. Hunt leg. (UCDC); Puerto Maldonado, 1 male, 9.I.1984, L. Huggert leg. 
(PMAE); Huanuco: Tingo Maria (Cueva de las Pavas), 8 males, 26-30.I.1984, L. Huggert leg. (PMAE); Tocache, 1 male, 2.II.1984, L. Huggert leg. (PMAE). BRAZIL, Amazonas: Manaus (INPA, Reserva Ducke, forest), 1 male, 4.IX.1990, Malaise trap (INPA); (Reserva Ducke), 43 males, 8.IV-29.VII.1992, glue trap, 1m or $2 \mathrm{~m}$ or $10 \mathrm{~m}$ or $20 \mathrm{~m}$, Vidal \& Vidal leg. (INPA); 1 male, 9.IX.1986, Ulissez leg. (INPA); 39 males, Reservas 1208, 1210, 1112, 113, 1301, 22:X.1982-17.X.1987, Malaise trap, B. Klein leg. (INPA); 2 males, Reserva Campina, 19.IV.1992, glue trap, 1m, Vidal \& Vidal leg. (INPA); 5 males, 3.VIII-9.IX.1983, pan trap, N.F. Johnson (OSUC); 1 male Rio Javari, X.1979, M. Alvarenga leg. (PMAE); 2 males, VI.1976, F.M. Oliveira (PMAE); Pará: Tucuruí (Rio Tocantins), 10 males, 9.XI.1985-17.XI.1986, interception trap, N. Degalier leg. (MPEG); Altamira, 4 males, 22.IV.1986, interception trap, N. Degalier leg. (MPEG); (Rio Mapuera, above Assumpção), 1 male, 13.VI.1986, Malaise trap (INPA); Serra Norte, 1 male, Estação N5-N1, 6.X.1986, interception trap, N. Degalier leg. (MPEG); 1 male Manganês road, 8.VI.1993, Malaise trap (MPEG); 1 male, Itacaiunas, XI-XII.1982, CDC light trap, J. Arias leg. (OSUC); Rondônia: Ariquemes (Rio Ji-paraná), 1 male, 28.X.1986, Malaise trap, J.A. Rafael leg. (INPA); Mato Grosso: Sinop, 6 males, XI.1975, M. Alvarenga leg. or II.1976, O. Roppa leg. (PMAE); Distrito Federal: (Parque Nacional, 1000m), 1 male, 11.III.1970, J.M. \& B.A. Campbell (PMAE); São Paulo: Serra da Bocaina, 2 males, XI.1969, M. Alvarenga leg. (PMAE); São Carlos (Fazenda Canchim, forest or cerrado), 20 males, 21.III.1985-27.XII.1989, sweep or Malaise trap, A.S. Soarez or L.A. Joaquim or N.W. Perioto leg. (DCBU, UFES); (Parque Ecológico, cerrado), 3 males, 9-13.I.1987, sweeping, F. Passos leg. (DCBU); Bauru (Estação Ecológica, cerrado), 9 males, 14.XI.1990-1.VI.1993, pan trap, S.S. Ruiz leg. (UFES); Paraná: Ponta Grossa, (Vila Velha, Reserva Iapar, Br 376), 2 males, 25.I-23.V.1988, Colombo, (Embrapa, Br 476, km 20), 2 males, 17-31.VIII.1987, Malaise trap, Levantamento Profaupar (DZUP). BOLIVIA, Santa Cruz: (Rio Mamoré, $2 \mathrm{~km} \mathrm{~N}$ mouth of Rio Chaporé), 1 male, 28.-31.VII.1965; Bouseman \& Lussenhop leg. (AMNH).

Variations. Clypeus more developed laterally; corners of the vertex slightly more angulate; notauli very convergent behind; depressions of the tergite II slightly more or less deep; tufts of the tergite thicker, and more hairy; some specimens from São Paulo (Brazil) without depression in the tergite II, tufts larger; tufts small on a tubercle and with the long lateral hair distant from the tuft, apex of the paramere smaller, ventral ramus of the aedeagus shorter.

Remarks. This species was known only to Colombia, and now it is recorded for the first time to Ecuador, Peru, Brazil and Bolivia.

Distribution. Colombia, Ecuador, Peru, Brazil (Amazonas, Pará, Rondônia, Mato Grosso, Distrito Federal, São Paulo, Paraná), Bolivia.

\section{Dissomphalus incomptus Evans, 1964}

Diagnosis. Male: mandible tridentate. Clypeus rounded with median tooth. Frons coriarious, punctures small, shallow, separated by 0.5-3.0 X their diameters. Vertex slightly convex, corners rounded. Propodeum wholly rugose. Tergite II with a pair of minute microtubercles closer to the anterior margin of the tergite than the 
its middle, in the median fourth of the width of the tergite. Hypopygium with slender stalk, 1.0 X the length of hypopygium, posterior margin concave, corners rounded.

Genitalia. Paramere with wide, truncate and oblique apex, with dorsal corner produced and sharpened; aedeagus with ventral ramus conspicuous and long, but slightly shorter than dorsal body, transversal section flattened, basal half wide, apical half not so wide, with inner margin excavated, rounded apex slightly diverging, so that the ramus is sinuous in the apical half; dorsal body very complex, with four pairs of apical lobes, the dorsal pair wide, laminar, inner margin straight, outer margin convex, with an inner apical cone, base of the lobe higher than apex; the second dorsal pair is lateral and leaf-shaped, laminar; the third pair is a ventral filament smooth and cylindrical; the ventral pair is stout, with an apical teeth and a ventral flattened filament inclined downward, lobe wholly covered by teeth directed downward, being sharpened in the filament and rounded wherever; base of the dorsal body with a pair of a small dorsal filaments slightly above the leaf-shaped lobe; apodema not extending beyond the elliptical genital ring.

Material examined. PARAGUAY: Carumbá, 1 male, 1.II-8.III.1966, R. Golbach leg. (FIML). BRAzIL, Santa Catarina: Seara (Nova Teutônia), 1 male, XII.1964, F. Plaumann leg. (UCRC, paratype). New material: BRAzIL, São Paulo: Bauru (Estação Ecológica), 1 male, 9.XII.1993, pan trap, S.S. Ruiz leg. (UFES); Ibitinga (rubber-tree crop), 9 males, Möricke trap (UFES); Luis Antônio (Estação Ecológica do Jataí), 1 male, 4.VII.1989, sweeping, L.A. Joaquim leg. (DCBU); São Carlos (Fazenda Canchim, forest), 1 male, 16.VIII.1990, sweeping, L.A. Joaquim leg. (DCBU); São Paulo, 1 male, 14.XI.1972, G.E. Bohart leg. (EMUS); 4 males as data as paratype, except date I.1963-V.1971 (CNCI, MCZH); Paraná: Jundiaí do Sul (Fazenda Monte Verde), 1 male, 8.XII.1986, Malaise trap, Levantamento Profaupar (DZUP); Foz de Iguaçu, 2 males, 11.XII.1966, Zooexpedition (DZUP).

Variations. Vertex straight, frons less coriarious, with punctures more sparse; tubercles slightly more distant each other; propodeum with texture weaker; 2 specimens without tubercles; apex of ventral ramus not so rounded, specimen from Paraguay with ventral ramus hardly sinuous and apex less rounded.

Remarks. This species is recorded for the first time to São Paulo and Paraná (Brazil).

Distribution. Brazil (São Paulo, Paraná, Santa Catarina), Paraguay.

\section{Dissomphalus infissus Evans, 1969}

Fig. 9

Diagnosis. Male: mandible tridentate. Clypeus trapezoidal. Frons coriarious, punctures small, shallow, separated by 0.5-2.0 X their diameters. Vertex straight, with a small median depression, corners rounded. Tergite II with a pair of very shallow and circular depressions, distant each other $1.2 \mathrm{X}$ their diameters, distant of lateral of tergite $0.5 \mathrm{X}$ their diameters, not reaching the anterior margin, each depression with a hairy linear tubercle, inclined, with posterior part directed inward, latero-anterior area of the depression sparse-haired. Hypopygium with a slender stalk, $1.3 \mathrm{X}$ the length of hypopygium, posterior margin straight, corners rounded. 
Genitalia (Fig. 9). Paramere short and wide, dorsal margin evenly very developed, apex concave and very produced dorsally; volsella with a stout protuberance near the digitus, base of volsella with a group of teeth; aedeagus with ventral ramus very short, base wide and the apical half thin, slightly convergent, with apex very sharpened, inner margin of the base sinuous, outer margin expanded laterally, so that the ramus surrounds the dorsal body laterally, this margin with a small tooth; dorsal body very wide with apex in lateral view, laminar, the lamina completely folded longitudinally in ventral side, the inner lamina membranous, sinuous, hairy inside, the outer lamina with a series of grooves; in dorsal view the body is slightly wider in the base; the inner ventral margin of the basiparamere angulate; apodema not extending beyond the elliptical genital ring.

Material examined. ArgentinA, Salta: Orán (Abra Grande), 1 male, 1623.II.1967, Malaise trap, R. Golbach leg. (FIML, holotype). New material: BRAZIL, São Paulo: S.J. Barreiro (Serra da Bocaina), 1 male, 13-17.I.1969, Porter \& Garcia leg. (MCZH); Teodoro Sampaio, 2 males, XII.1977, M. Alvarenga leg. (PMAE); Paraná: Colombo, Embrapa, Br 476, km 20, 1 male, 21.IX.1987, Ponta Grossa, (Vila Velha, Reserva Iapar, Br 376), 2 males, 8.II-14.III.1988; São José dos Pinhais (Serra do Mar, Br 277, km 54), 1 male, 17.VIII.1987, Levantamento Profaupar, Malaise trap (DZUP). ARGENTINA, Salta: Orán (Abra Grande), 2 males, 18.IV-5.V.1969, C. Porter leg. (MCZH).

Variations. Apex of the paramere more produced, ventral margin of paramere more angulate apically; specimens from Teodoro Sampaio (São Paulo) with the produced portion of the apex of the paramere wider.

Remarks. This species was known from only the types series. Now, 2 more specimens were analyzed from the same place, and it is recorded for the first time to Brazil.

Distribution. Brazil (São Paulo, Paraná), Argentina (Salta).

\section{Dissomphalus mendicus Evans, 1969}

Fig. 10

Diagnosis. Male: mandible bidentate. Clypeus subtrapezoidal. Frons weakly coriarious, punctures shallow, very small, separated by $2-5 \mathrm{X}$ their diameters. Vertex nearly straight, corners rounded. Tergite II with a pair of circular shallow depressions, distant each other $3 \mathrm{X}$ their diameters, reaching the anterior margin of the tergite, with a very minute hairy tubercle, the depression very lateral, distant from the lateral of the tergite $0.5 \mathrm{X}$ their diameters. Hypopygium with a slender stalk, 1.3 $\mathrm{X}$ the length of hypopygium, posterior margin straight, corners somewhat angulate.

Genitalia (Fig. 10). Paramere with concave apex, with dorsal corner produced; volsella with cuspis with truncate apex, digitus with long and sharpened basal projection; aedeagus with ventral ramus shorter than the dorsal body, base extremely wide, surrounding the dorsal body ventral and laterally, apical half thin; inner apical margin very concave, so that the apical half of the ramus is sinuous, with apex rounded and shortly parallel; dorsal body with two pairs of apical lobe, the outer laminar large, broadly rounded in dorsal and lateral view, surface vertical and 
convex outside, base of the outer lobe expanded inward; inner lobe membranous, laminar, surfaces vertical, small and sinuous; with a median lobe very stout and nearly cylindrical between the inner and outer lobes, shorter than the inner lobe; apodema extending slightly beyond the elliptical genital ring.

Material examined. ARgENTINA, Tucumán: El Soledad (11 km W Las Cejas), 1 male, 17.VI-12.VII.1967, L. Stange leg. (FIML, holotype).

Distribution. Argentina (Tucumán).

\section{Dissomphalus microstictus Evans, 1969}

Fig. 11

Diagnosis. Male: mandible bidentate. Clypeus trapezoidal. Frons strongly coriarious, densely punctate, punctures shallow, large, separated by $0.1-1.0 \mathrm{X}$ their. Vertex straight, corners somewhat rounded. Ocelli large. Head developed behind the eye. Propodeal disc with only the median carina. Tergite II with two depressions shallow, large and subcircular, nearly reaching the posterior margin of the tergite I, distant each other $0.8 \mathrm{X}$ their diameters, each one with a minute hairy median tubercle, lateral area of depression with hairs. Hypopygium with a slender stalk, 1.3 $\mathrm{X}$ the length of hypopygium, posterior margin straight, corners rounded.

Genitalia (Fig. 11). Paramere very wide, dorsal margin very evenly developed, apex produced and sharpened; volsella hairy, digitus smooth in upper margin; aedeagus with ventral ramus extremely short, slightly higher than the base of the paramere, laminar, wide, surfaces horizontal, inner margin parallel, outer margin convergent, apex thin and rounded, outer margin with an apical filament very long, nearly with the same size of the ramus, slightly arched, dorsal body large, laminar, surfaces vertical, base wider in dorsal view, body is very wide in lateral view, with rounded apex directed downward, ventral margin complex, serrated with rounded teeth, inner surface hairy; apodema extending beyond the elliptical genital ring.

Material examined. ARgENTINA, Tucumán: El Solidad (Las Cejas), 1 male, 3-19.VI.1966, L. Stange leg. (FIML, holotype); 13 males, 8.XII.1967-22.III.1968 (FIML, UCRC, LACM paratypes); 1 male, $11 \mathrm{~km}$ E. las Cejas, 22.V-14.VIII.1968, L. Stange leg. (LACM). New material. BrAZIL, Amapá: Serra do Návio, 1 male, 14.V.1991, interception trap, N. Degalier leg. (MPEG); Amazonas: Manaus (Reserva Ducke or 1208 or 1210 or km 60, Malaise or CDC light traps), 7 males, B. Klein or N.D. Penny or J. Arias leg. (INPA); Pará: Tucuruí (Rio Tocantins, interception trap), 3 males, N. Degalier leg. (MPEG); Pernambuco: Caruaru, 10 males, IVVII.1972, M. Alvarenga or J. Lima leg. (PMAE); Distrito Federal: Brasília (Reserva Ecológica do IBGE, 1555'58'S, 4751'02'W), 24 males, 6.VI.1980-2.IX.1982, window or Malaise traps, J. Dalmáceo leg. (IBGE); São Paulo: Serra da Bocaina, 2 males, VIII.1973; M. Alvarenga leg. (PMAE); Serra da Bocaina, 1 male, 1317.I.1969 (MCZH); Teodoro Sampaio, 1 male, VIII.1973, Oliveira leg. (PMAE); Paraná: Antonina (Reserva Sapitanduva, Malaise trap), 1 male, 25.V.1987, São José dos Pinhais (Serra do mar, Br 277, km 54), 6 males, 11.VIII.1986-28.IX.1987, Levantamento Profaupar, (DZUP); Santa Catarina: Seara (Nova Teutônia), 1 male, III.1958, F. Plaumann leg. (MCZH); BoliviA, Santa Cruz: Rio Ichilo (locality A), 2 males, 22.VII.1965, J.K. Bouseman leg. (AMNH). ARGENTINA: 7 males, same data as holotype, except date 1.XI.1967-21.III.1968, C. Porter leg. (MCZH). 

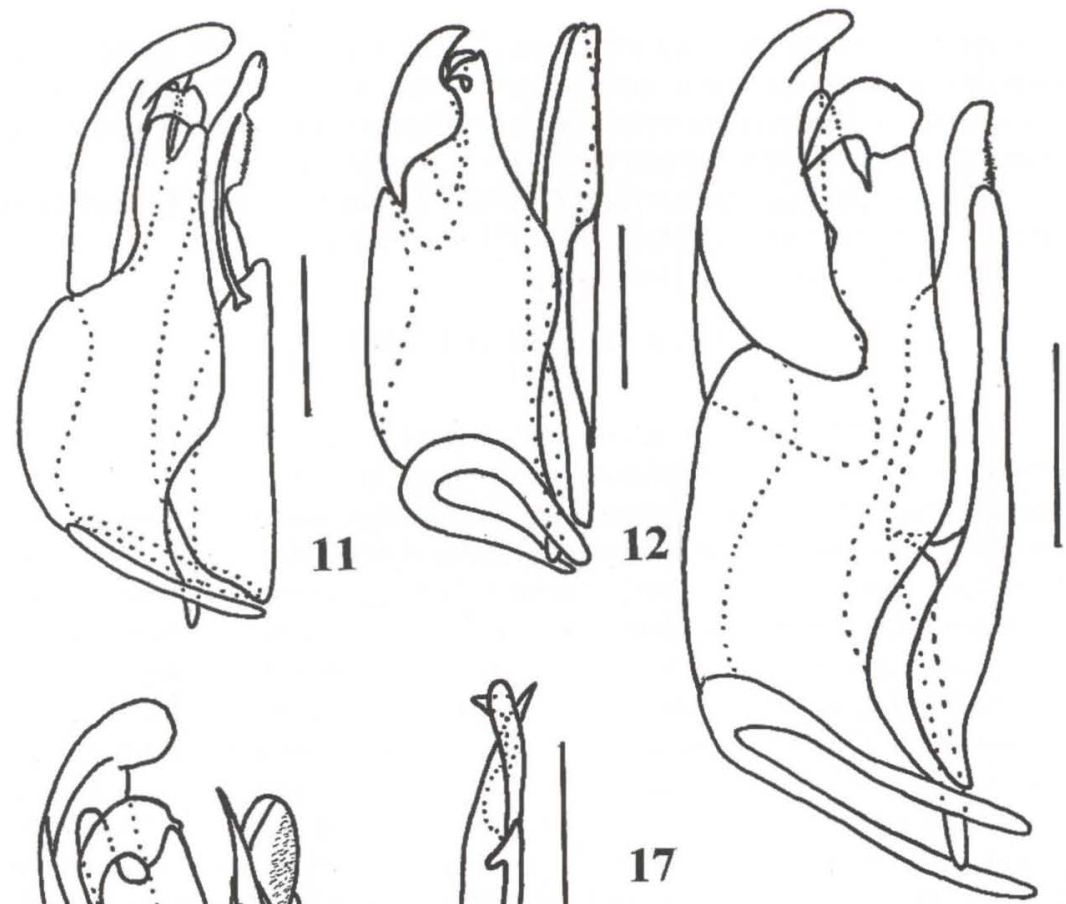

13
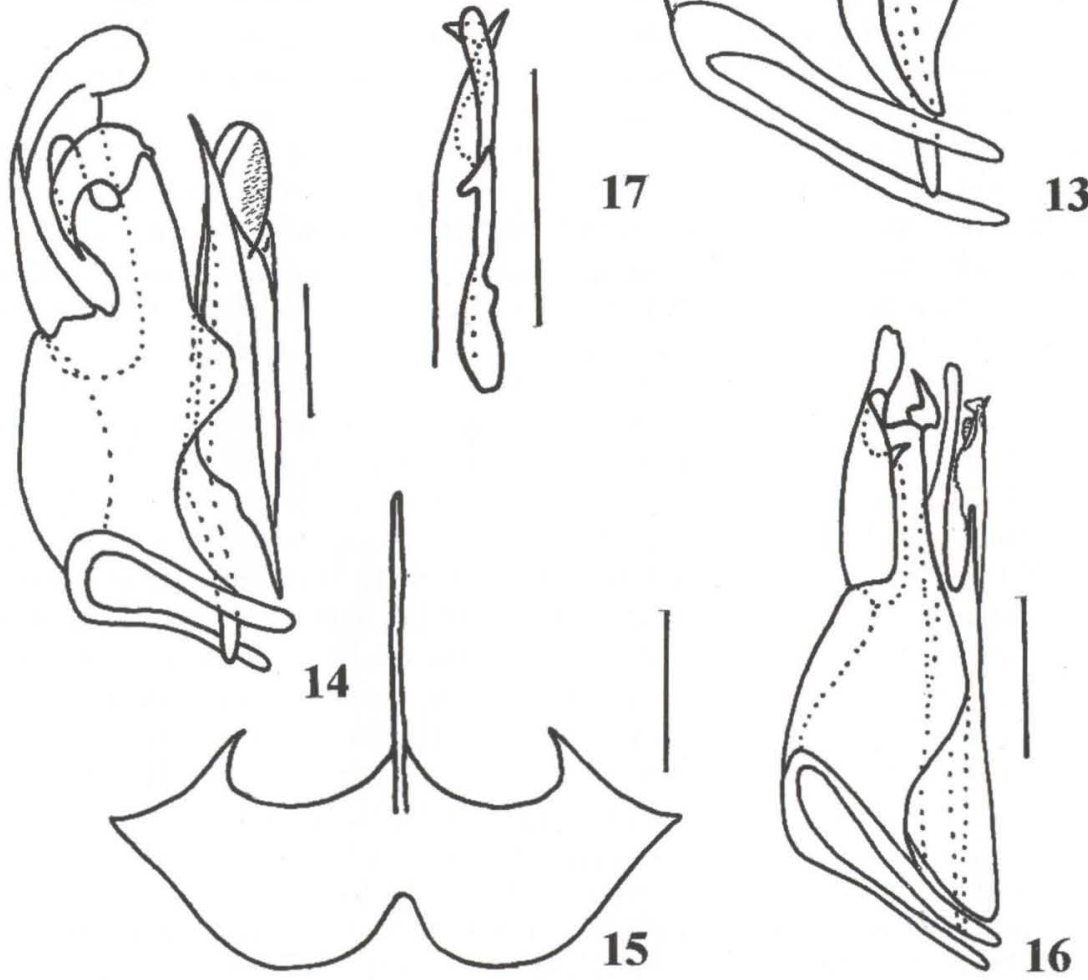

Figs 11-17. (11-14) Genitalia, ventral: (11) D. microstictus; (12) D. mirabilis; (13) D. nanellus; (14) D. napo; (15-17) D. punctatus: (15) hypopygium; (16) genitalia, ventral; (17) apex of dorsal body of aedeagus, dorsal. Scale bar $=115 \mu \mathrm{m}$. 
Variations. Temple shorter; specimens from São Paulo and some from Paraná without tergal processes; ventral margin of paramere angulate apically; base of volsella higher; with filament of the ventral ramus of aedeagus is thicker in specimens from Brasília and very conspicuous in specimens from Caruaru.

Remarks. This species was known only from the type-locality and type series. Now it is recorded for the first time to Brazil, where it is widespread, and Bolivia. The long filament of the ventral ramus of aedeagus is very peculiar to this species.

Distribution. Bolivia, Brazil (Amapá, Amazonas, Pará, Pernambuco, Distrito Federal, São Paulo, Paraná, Santa Catarina) Argentina (Tucumán).

\section{Dissomphalus mirabilis Evans, 1966}

Fig. 12

Diagnosis Male: mandible bidentate with a broad upper cutting edge. Clypeus evenly little projected forward, with a small median tooth, with a pair of large horns projected upward. Frons weakly coriarious, punctures shallow, separated by 1-2 X their diameters. Vertex straight, with corners angulate. Head developed behind the eye tops. Tergite II with a pair of elliptical, oblique and deep depression, $0.5 \mathrm{X}$ as long as tergite is, nearly reaching the anterior margin of tergite, separated each other by slightly less than their greatest diameter. Hypopygium short, with a median stalk dilated apically, $1.5 \mathrm{X}$ the length of hypopygium, posterior margin concave.

Genitalia (Fig. 12). Paramere with a sharpened apex arched inward, dorsal margin concave, ventral margin much developed and angulate, base of the paramere elevated in ventral side; volsella elevated, slightly less high than the apex of the paramere; aedeagus with ventral ramus as long as dorsal body, basal half thin, slightly dilated below, apical half abruptly wide with both inner and outer margins slightly concave, apex almost truncate with rounded corners; dorsal body with a pair of apical lobe with concave sides, converging apically in dorsal view, base of lobe with a pair of expansion with rounded apex, high in lateral view; apodema extending beyond the elliptical genital ring.

Female. Description: length of body $2.5 \mathrm{~mm}$. Color: wholly castaneous, eye darker.

Head. Weakly coriarious, punctures small, sparse, separated by 3-6 X their diameters. Mandible thinner apically, bidentate. Clypeus with a high median carina, divided in two apically, apical margin projected forward medially and with a pair of lateral conical teeth. First four antennal segments in ratio of 9:2:1:1, segment XI $2 \mathrm{X}$ as thick as long. Frons with a longitudinal depression anteriorly. Eye subcircular with about 9 small facetes. LH $1.5 \mathrm{X} \mathrm{WH}$, sides of head almost parallel. Vertex coriarious, corners rounded.

Mesosoma. Weakly coriarious, with punctures small and very sparse. Pronotal disc $1.22 \mathrm{X}$ as long as wide. Mesoscutum $0.3 \mathrm{X}$ as long as pronotal disc, slightly embraced by the anterior margin of propodeum. Propodeal disc with maximum width $1.25 \mathrm{X}$ the minimum width, spiracle in lateral position. Forefemur $2 \mathrm{X}$ as long as thick. Midtibia spinose. 
Gaster. Petiolate, weakly coriarious, transversal section circular, 1.6 X as long as mesosoma.

Material examined. BrazIL, Paraná: Rondon, 6 males, IX-XII.1952, F. Plaumann leg. (MCZH, UCRC, paratypes). New material: BrAZIL, São Paulo: Ubatuba (Atlantic rain forest), 1 male, 1 female in copula, 19.XII.1990, Möricke trap, N.F. Cristo leg. (DCBU); Paraná: Rondon, 3 males, 7-16.IX.1952, F. Plaumann leg. (MCZH).

Remarks. This species was know only from Paraná (Brazil) from males of types series, and now male and female in copula are recorded for the first time to São Paulo. This species presents a typical bihorned clypeus and although, the sexual dimorphism is very strong in this genus, the female presents the clypeus strongly bicarinate. The elevated and angled ventral base of the paramere is peculiar, but the aedeagus is one of the most simple in this genus.

Distribution. Brazil (Paraná, São Paulo).

\section{Dissomphalus nanellus Evans, 1969}

Fig. 13

Diagnosis. Male: mandible tetradentate. Clypeus subtrapezoidal. Frons weakly coriarious, punctures inconspicuous. Vertex straight, corners broadly rounded. Pronotal disc with a very weak anterior carina. Tergite II a pair of very shallow ovoid depression reaching the anterior and lateral margin of the tergite, $0.5 \mathrm{X}$ as long as tergite, distant each other $2 \mathrm{X}$ their width, each one with a small hairy tubercle, lateral margin of depression with some setae. Hypopygium with median stalk $0.9 \mathrm{X}$ the length of hypopygium, posterior margin slightly concave, with two rounded projections.

Genitalia (Fig. 13). Paramere with base of the dorsal margin much developed, apex wide, blunt and oblique; volsella with cuspis very long, nearly reaching the apex of the paramere; aedeagus with ventral ramus long, evenly thin, laminar, with horizontal surfaces, margin smooth, the two apical thirds divergent, and the basal third convergent; dorsal body with two pairs of apical lobes, the ventral pair laminar, surfaces vertical, projected downward apically, dorsal margin developed and apex rounded in lateral view, inner surface hairy, the dorsal pair arched outward medially, inner margin serrated with small and rounded teeth dorsally; apodema not extending beyond the elliptical genital ring; basiparamere angulate in ventral side.

Material examined. JAMAICA: Hardway Gap (4000 feet), 1 male, 25.VII.1966, Howden \& Becker leg. (MCZH, paratype).

Remarks. The ventral ramus of the aedeagus is usually wide basally, but in this species it is wholly thin.

Distribution. Jamaica.

\section{Dissomphalus napo Evans, 1979}

Fig. 14

Diagnosis. Male: mandible bidentate. Clypeus trapezoidal. Frons somewhat strongly coriarious, densely puntacte, punctures large, shallow, separated by $0.2-1.0$ $\mathrm{X}$ their diameters. Vertex straight, with corners not so rounded. Tergite II with a 
pair of shallow, not so large and circular lateral depressions, distant from the anterior margin $0.5 \mathrm{X}$ their diameters and distant each other $3 \mathrm{X}$ their diameters, each one with a tuft of dense hairs directed backward. Hypopygium with a slender stalk, 1.3 $\mathrm{X}$ the length of hypopygium, posterior margin concave.

Genitalia (Fig. 14). Paramere wide, with rounded and wide apex, dorsal margin developed, ventral margin with a strong excavation; apex very arched inward in ventral view; volsella with digitus stout, large and arched, nearly as long as the half length of the paramere; aedeagus with ventral ramus longer than dorsal body, apex laminar and vertical, dilated and rounded in lateral view, base long, $3 \mathrm{X}$ longer than the apex, wide; dorsal body simple, reduced to a pair of long conical projections; ventral margin of the basiparamere produced and angulate medially; apodema extending beyond the elliptical genital ring.

Material examined. ECUADOR, Napo: Limoncocha (on Rio Napo), 6 males, 20.I-19.III.1974, B.A. Drummond leg. (FSCA, LACM, paratypes). New material: BRAZIL, Amazonas: Manaus (Reserva 1208), 1 male, 8.X.1985, Malaise trap, B. Klein leg. (INPA); Estirão do Equador (Rio Javari), 1 male, X.1979, M. Alvarenga leg. (PMAE). ECUADOR, Napo: Tena, 4 males, 15.II.1986, sweep, A.T. Finnamore leg. (PMAE); Baeza-Tenaroad (12km S of Jondachi), 1 male, 18.II.1986, sweep, T.W. Thormin \& J. Wojcicki leg. (PMAE); Limoncocha, 1 male, 28.VI.1976, S. \& J. Peck leg. (PMAE); Huahua Sumaco (km 44-45 on Hollin-Loreto road), 13 males, 15-22.XII.1989, Malaise trap, M. \& J. Wasbauer, H. Real leg. (UCDC); Mor. Santiago: Miazal (50km SE Macas, 300m), 5 males, 4-7.I.1993, M. \& J. Wasbauer leg. (UCDC); Pastaza: Puyo (23 km SE), 1 male, 19.V.1977, J.P. Spangles \& R.R. Givens leg. \#58 (USNM); 25 km N Puyo, 1 male, 4.VIII.1976, S. \& J. Peck leg. (PMAE). Peru, Loreto: Iquitos (Barillal), 1 male, 10.II.1984, L. Huggert leg. (PMAE). Paraguay: Carumbé, 1 male, 1.II.-8.III.1966, R. Golbach leg. (MCZH).

Variations. Depression of tergite II deeper or shallower, tufts more or less dense, their hair directed outward apically.

Remarks. This species was known only from the type-locality and now it is recorded for the fist time to Peru, Brazil and Paraguay.

Distribution. Ecuador, Peru, Brazil (Amazonas), Paraguay.

\section{Dissomphalus plaumanni Evans, 1964}

Diagnosis. Male: mandible tetradentate. Clypeus trapezoidal. Frons coriarious, punctures large, shallow, separated by $0.1-1.0 \mathrm{X}$ their diameters. Vertex straight with rounded corners. Scutellar groove dilated at the middle. Tergite II with a pair of rounded depressions, distant each other $1.5 \mathrm{X}$ their diameters, distant from lateral margin of tergite $1.5 \mathrm{X}$ their diameters, distant from anterior margin of tergite 0.6 $\mathrm{X}$ their diameters, each one with a tuft of hairs directed back and inward, anterior margin of depression with some hairs. Hypopygium short, with median stalk dilated apically, $1.0 \mathrm{X}$ the length of hypopygium, posterior margin slightly convex with a small conical expansion.

Genitalia. Paramere with acute apex and arched inward, dorsal margin much developed, mainly at the base; volsella with digitus with a rounded dorsal expansion 
basally; aedeagus with ventral ramus short, as high as base of cuspis, wide, inner and outer margins straight and slightly convergent, apex acute with outer margin slightly concave, ramus laminar, ventral surface slightly directed outward; dorsal body with a pair of apical lobes, laminar, wide with rounded apex in lateral view, compressed in dorsal view, wider below the apex, base of the aedeagus high in lateral view; apodema not extending beyond the subcircular genital ring.

Material examined. BrazIL, Santa Catarina: Seara (Nova Teutônia), 2 males, XII.1947 and 26.II.1964, F. Plaumann leg. (UCRC, one paratype). New material: MeXICO, Chiapas: (300 feet, 20 mi. N. Huixtla), 10 males, 6.VI.1969, W.R.M. Mason leg. (CNCI, PMAE); Palenque, 1 male, 10.IX.1974, G. Bohart leg. (EMUS). Belize: Middlesex (125m), 1 male, 27.IV.1965, E.C. Welling leg. (CNCI). GUATEMALA: Izabal (Las Escolbas, 200m), I male, VI.1987, Malaise trap, Sharkey leg. (PMAE). Costa RicA, San Coto de Vito Brus: Las Cruces (1200m), 47 males, 9.VII-12.IX.1982, Malaise trap, B. Gill leg. (CNCI, PMAE); San Jose: Pan-Am Hwy (14 rd mi. N. San Isidro de General, ca. 1600m), 1 male, 2023.VI.1974, W.A. Harding \& J.P. Donahue leg. (LACM); Zurqui de Moravia $\left(10^{\circ} 05^{\prime} \mathrm{N}, 84^{\circ} 02^{\prime} \mathrm{W}, 1600 \mathrm{~m}\right), 2$ males, V.1994, Malaise trap, P. Hanson leg. (LACM); Alajuela: (5 mi. N. Quesada, 750 feet), 2 males, 20.II.1964, H. Evans leg. (MCZH); Peñas Blancas (Cord. Tilaran, 700m, rain forest), 2 males, IX.1986II.1987, Malaise trap, E. Cruz leg. (PMAE); Heredia: (ca. $12 \mathrm{~km} \mathrm{SW} \mathrm{Horquetas,}$ Rara Avis, 550m), 1 male, 18-23.I.1989, D.A. Grimaldi leg. (AMNH); Monteverde: 1 male, 2-9.VII.1983, D. Lindman leg. (PMAE). PANAMA, Canal Zone: Barro Colorado, 2 males, 26.VII.1956, C.W. \& M.E. Rettenmeyer leg. (CNCI); 2 males, 3-13.VI.1983, B. Gill leg. (PMAE); 1 male, 30.I.1980, H. Wolda leg. (UCDC); 1 male, 5.IX.1978, R.B. \& L.S. Kimsey leg. (UCDC); Pan Prov.: Las Cumbres, 1 male, 28.VIII.1982, H. Wolda leg. (PMAE); Canal PAN (Lion Hill Island) 1 male, V.1982, R.B. Kimsey (UCDC). TRINIDAD \& Tobago, Trinidad: Port of Spain, 1 male, 30.XII.1944, plane NC30093, Iyco116, lote 45.4224 (USNM); Simla Res. Station, 5 males, 2-15.VI.1981, Hanson \& Clemons leg. (EMUS). ECUADOR, Napo: Limoncocha, 1 male, 28.VI.1976, S. \& J. Peck leg. (PMAE); Tena (forest), 1 male, 20.II.1986, Malaise trap, A.T. Finnamore leg. (PMAE); Huahua Sumaco, km 44-45 on Hollin-Loreto road, 2 males, 15-22.XII.1989, Malaise trap, M. \& J. Wasbauer, H. Real leg. (UCDC); Pichincha: (near Santo Domingo, 2000'), 1 male, 714.V.1988, Hanson \& Bohart leg. (EMUS); Mor. Santiago: Miazal $(50 \mathrm{~km}$ SE Macas, 300m), 3 males, 4-7.I.1993, M. \& J. Wasbauer leg. (UCDC); Pichincha: Tinalandia (16km SE Santo Domingo, 500m), 1 male, VI-VIII.1985, S. \& J. Peck leg. (PMAE); Rio Palenque Station, 1 male, 27.II.? (PMAE). PERU Loreto: Iquitos (Quistococha), 1 male 8-10.II.1984, L. Huggert leg. (PMAE). BRAZIL, Amazonas: Manaus (Reserva Ducke, Campina, 1208, 1210, 1112, 1113 or 1301), 11 males, 10.X.1985-17.VII.1992, Malaise or glue trap, Vidal \& Vidal leg., Ulisses leg. or B. Klein leg. (INPA); Estirão do Equador (Rio Javari), 2 males, X.1979, M. Alvarenga leg. (PMAE); Pará: Oriximiná (Alcoa Mineração, Rio Trombetas), 1 male, $7-$ 25.X.1982, Malaise trap, Rafael, Binda \& Vidal leg. (INPA); Belém (Fazenda Morelândia), 1 male, 26.IV.1995, sweeping, Penteado-dias leg. (DCBU); Santarém 
Novo (Fazenda Jaburi), 1 male, 7-9.I.1993, Suspensa trap 3m, J. Dias leg. (MPEG); Altamira (km 18), 1 male, 23.IX.1985, interception trap, N. Degalier leg. (MPEG); Tucuruí, 1 male, 9.XI.1985, interception trap, N. Degalier leg. (MPEG); (Fazenda Taperinha), 2 males, 19-22.XI.1969, J.M. \& B.A. Campbell leg. (CNCI); Maranhão: 1 male 11.III.1987; pan trap (UFES); Imperatriz (Ribeirãozinho), 1 male, VIII.1989, Malaise trap, F.F. Ramos leg. (MPEG); Acre: Porto Acre (Humaitá), 4 males, 15.VI-2.VII.1992, Suspensa trap 1.6m, Gorayeb, Pena, Henriques \& Edmar leg. (MPEG); Rondônia: Ouro Preto do Oeste (L. 212, gleba 21B, lote 25, Suspensa trap 20m), 1 male, F.F. Rams leg. (MPEG); Rio Guaporé (opposite mouth of Rio Barnes Bolivia), 2 males, 23.IX.1964, J.K. Bouseman \& J.L. Lussenhop leg. (AMNH); Pernanbuco: Caruaru, 1 male, IV.1972, M. Alvarenga leg. (PMAE); Rio de Janeiro: Silva Jardim, 1 male, VIII.1974, F.M. Oliveira leg. (CNCI); Rio de Janeiro, 7 males, I.1972, M. Alvarenga leg. (PMAE); Represa Rio Grande, 3 males, II.1972, M. Alvarenga leg. (PMAE); Ilha Jaguanum, 2 males, 3.IX-5.X.1982, D. Hunt leg. (UCDC); São Paulo: Ibitinga, 1 male, 5.IV.1989 (UFES); São Carlos (Fazenda Canchim, forest), 3 males, 19.X.1989-28.X.1990, sweeping, L.A. Joaquim leg. (DCBU); Luiz Antônio (Estação Ecológica do Jataí), 3 males, 23.IX.1988-14.IX.1991, sweeping, A.S. Soares or L. A. Joaquim leg. (DCBU); Paraná: Jundiaí do Sul (Fazenda Monte Verde), 2 males, 6.X.1986, Colombo (Embrapa, Br 476, km 20), 5 males, 20.VII-21.IX.1987, Ponta Grossa (Vila Velha, Reserva Iapar, Br 376), 6 males 21.IX.1987-20.II.1988, Telêmaco Borba (Reserva Samuel Klabin), 10 males, 11.VIII.1986-14.IX.1987, São José dos Pinhais (Serra do Mar, Br 277, km 54), 13 males, 20.X.1986-7.XII.1987, São José dos Pinhais (Serra do Mar, Br 277, km 54), 3 males, 20.X.1986-7.XII.1987, Malaise trap, Levantamento Profaupar, Malaise trap (DZUP); Santa Catarina: Seara (Nova Teutônia), 1 male, 19.III.1966, F. Plaumann leg. (MCZH). BoliviA, Beni: Rio Itenez (opposite Costa Marques Brazil), 10 males, 2-3.IX.1964, J.K. Bouseman \& J.L. Lussenhop leg. (AMNH); Santa Cruz: Rio Ichilo (Locality A), 1 male, 22.VII.1965, J.K. Bouseman leg. (AMNH).

Variations. Depression of the tergite II more distant each other and closer to anterior margin of the tergite; depression slightly smaller or shallow; hairs of the tuft of tergite II not projected inward (specimens from Costa Rica and Mexico) or not so directed backward (specimens from Manaus, Brazil); tufts more hairy (specimen from Trinidad \& Tobago); dorsal margin of the paramere much more developed and apodema extending beyond the genital ring in many specimens of a lot of localities; ventral ramus of the aedeagus much shorter (specimens from type-locality) or larger (some specimens from Ecuador)

Remarks. This is probably the most widespread species in the Neotropical region. It was know only from the type-locality (Brazil, Santa Catarina). The genitalia of $D$. plaumanni and $D$. fungosus are particularly similar.

Distribution. Mexico, Belize, Guatemala, Costa Rica, Panama, Trinidad \& Tobago, Ecuador, Peru, Brazil (Amazonas, Pará, Maranhão, Acre, Rondônia, Rio de Janeiro, São Paulo, Paraná, Santa Catarina), Bolivia. 


\section{Dissomphalus punctatus (Kieffer, 1910)}

Figs 15-17

Thaumatepyris punctatus Kieffer 1910b: 47-48. -Kieffer, 1914: 504.

Dissomphalus punctatus; Evans, 1964: 47-48. - Gordh \& Moczar, 1990: 225.

Glenobethylus montanus Kieffer, 1910b: 50-51. - Kieffer, 1914: 494-495.

Dissomphalus montanus; Evans, 1964: 46, 48-49. - Gordh \& Moczar, 1990: 224. Syn.n.

Diagnosis. Male: mandible bidentate. Clypeus trapezoidal with rounded corners. Frons strongly coriarious, punctures separated by $1.0 \mathrm{X}$ their diameters. Ocellar triangle far from vertex crest. Vertex slightly convex, with corners somewhat angulate. Tergite II with a pair of very shallow, small and rounded depressions, wholly covered by a dense tuft of hairs directed backward, depressions distant of anterior margin of tergite $1.0 \mathrm{X}$ their diameter, and distant each other 2.5 $\mathrm{X}$ their diameters. Hypopygium with median stalk $1.8 \mathrm{X}$ the length of hypopygium, posterior margin with a strong invagination and two rounded lobes (Fig. 15).

Genitalia (Fig. 16). Paramere with rounded apex much arched inward, dorsal margin straight; aedeagus with ventral ramus slightly shorter than dorsal body, sinuous and wide, with apical filament directed outward; dorsal body (Fig. 17) with two pair of apical lobes, the dorsal one as a filament with sharpened apex, inner surface hairy, vertical, the ventral one is longer, membranous, except by the outer-dorsal area, wide with rounded apex in lateral view, surfaces vertical and the inner one densely hairy; ventral side of basiparamere angulate medially; apodema extending beyond the elliptical genital ring.

Material examined. ECUADOR: Abitagua, 1 male, 2.IV.1940, Clarke-McIntyre leg. (MCZH). PERU, Cuzco: Cajon-Bergland (1500m), 1 male, 11.I.1901, S.V. Garlepp leg. (ZMHB, holotype 195), Cosnipata-Ebene (1000m), 1 male, 5.I.1901, S.V. Garlepp leg. (ZMHB, holotype 200, of D. montanus). New material: CosTA RICA, Heredia: La Selva Reserve Station, 2 males, 11-17.VI.1986; G. Bohart \& W. Hanson leg. (EMUS). ECUADOR, Napo: Huahua Sumaco (km 44-45 on Hollin-Loreto road), 5 males, 14-22.XII.1989, Malaise trap, M. \& J. Wasbauer, H. Real leg. (UCDC, EMUS); Tena, 1 male, 20.II.1986, Malaise trap, A.T. Finnamore leg. (PMAE). PERU, Madre de Dios: Puerto Maldonado, 1 male, 3.I.1984, L. Huggert leg. (PMAE).

Variations. Tufts of tergite smaller and less hairy.

Remarks. This species was know only from the type-locality and Ecuador and now it is recorded for the fist time to Costa Rica. The difference of density of hairs in the tuft of the tergite II of the gaster has probably led KIEFFER (1910b) to consider $D$. montanus and $D$. punctatus distinct species, but an exam of their genitalia confirmed the synonymy.

Distribution. Costa Rica, Ecuador and Peru.

\section{Dissomphalus puteolus Evans, 1969}

Fig. 18

Diagnosis. Male: mandible tridentate. Clypeus subtrapezoidal. Frons coriarious, densely punctate, punctures large, shallow, separated by $0.1-0.5 \mathrm{X}$ their diameters. Ocellar triangle with frontal angle nearly right. Vertex slightly convex 
with rounded corners. Eye large. Tergite II with a pair of circular lateral depressions somewhat deep, separated by $3 \mathrm{X}$ their diameters, reaching the anterior margin of the tergite, each one with a hairy tubercle placed near the inner margin, depression surrounded by sparse hairs, except anteriorly. Hypopygium with slender stalk, 1.8 $\mathrm{X}$ the length of hypopygium, posterior margin with a very angled invagination.
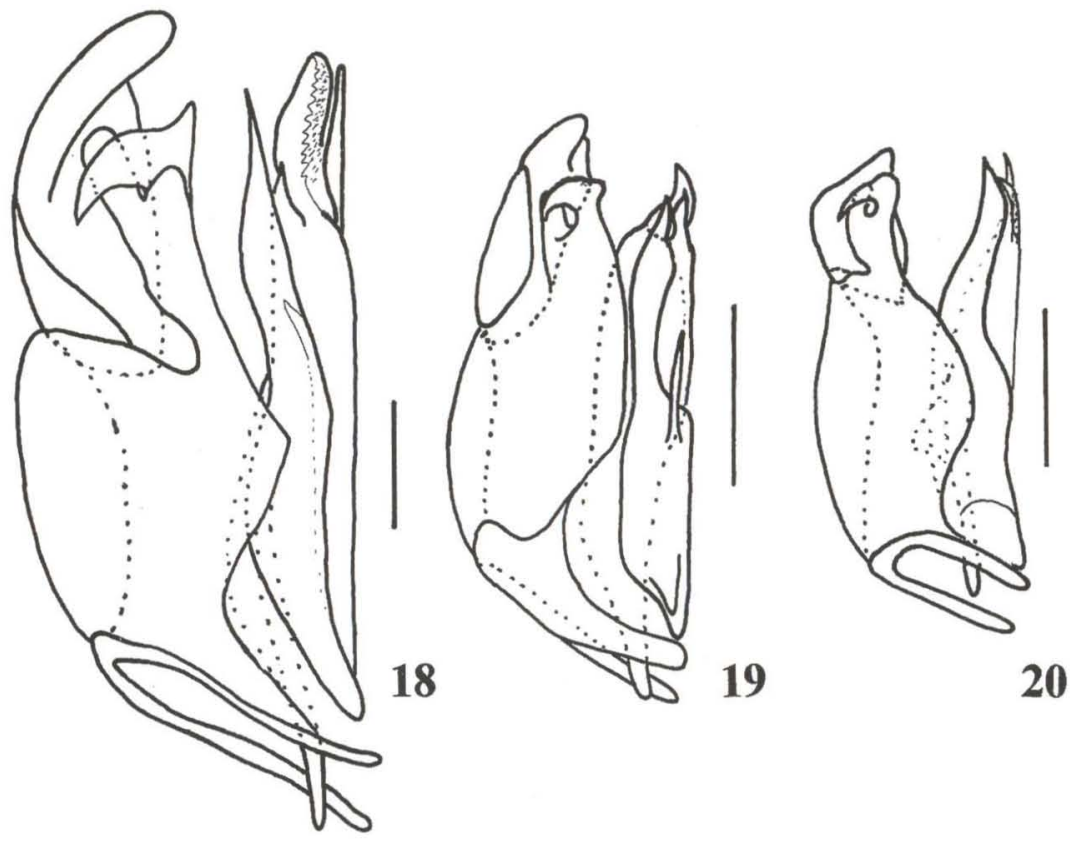

Figs 18-20. Genitalia, ventral. (18) D. puteolus; (19) D. xanthopus; (20) D. microtuberculatus sp.n.. Scale bar $=115 \mu \mathrm{m}$.

Genitalia (Fig. 18). Paramere not arched, apex oblique-truncate; volsella with digitus cylindrical, strongly arched with apex sharpened, digitus cuspis-shaped; aedeagus with ventral ramus longer than dorsal body, laminar, basal half wide with inner and outer margins parallel, apical half strongly divided in two longitudinal lobes, the inner lobe smaller than dorsal body with rounded apex and horizontal surfaces, the outer lobe is lateral in relation to dorsal body, large, with vertical surfaces, in lateral view wide and with dilated and blunt apex; dorsal body very complex, with four pair of apical lobes, the dorsal lobe, the smallest with a lateral projection nearly perpendicular, inclined downward, thin, inner margin with a median rounded excavation, base wider; the second pair (below the dorsal one) large, stout, membranous, hairy, with rounded and dilated apex; the third pair, laminar, surfaces vertical, wide, apical half narrowly progressively and convergent; the fourth pair (the most ventral one) long, as long as the second one, thin, with a perpendicular and thin projection, sharpened and directed outward, outer margin with a median rounded expansion wholly serrated at the border; apodema extending 
slightly beyond the elliptical genital ring, which is produced into the basiparamere laterally.

Material examined. ARgEnTINA, Tucumán: El Solidad (11 km W Las Cejas), 3 males, 3.VI.1966-27.V.1967, L. Stange leg. (FIML, holotype, paratypes).

Variations. Propodeum shorter (EVANS 1969a), depressions of the tergite II not reaching the anterior margin.

Distribution. Argentina, Tucumán.

\section{Dissomphalus rufipalpis Kieffer, 1910}

Dissomphalus rufipalpis Kieffer, 1910b: 44-45. - Kiefer, 1914: 496, 500.-Evans, 1962: 74-75. -Evans, 1964: 46. -Gordh \& Moczar, 1990: 225.

D. obliquus Evans, 1979: 276, 277, 279-280. - Gordh \& Moczar, 1990: 224. Syn.n.

Diagnosis. Male: mandible bidentate. Clypeus trapezoidal. Frons somewhat strongly coriarious, with punctures conspicuous, shallow, separated by $0.5-1.0 \mathrm{X}$ their diameters. Vertex slightly convex, corners rounded. Tergite II with a pair of large, elliptical and oblique sublateral depressions, distant each other $1.5 \mathrm{X}$ their length, nearly reaching the anterior margin, with a linear tuft of small hairs. Hypopygium with posterior margin nearly straight.

Genitalia. Paramere with dorsal margin much developed, base of the margin projected downward and with a small tooth; aedeagus with ventral ramus as long as dorsal body, laminar, with vertical surfaces, basal half wide, which is narrowing gradually to the apical half sinuous and very thin; dorsal body with two pair of apical lobes, the outer pair laminar, surfaces vertical, inner surface convex and hairy in the apical ventral area, the inner pair as a basal filament slightly inclined upward, with hairy surface; apodema extending beyond the elliptical genital ring.

Material examined. MeXICO, Vera Cruz: Cordoba, 1 male, 4.IX.1974, W. Hanson \& G. Bohart leg. (EMUS), 1 male, 1.I.1940, G. Bohart leg. (CASC). BELIZE (CASC): 1 male. Costa RicA: San Jose, 1 male, 1940, H. Schmidt (MZSP). Colombia, Valle: Central de Anchicaya $(30 \mathrm{~km}$ E. Buena Ventura, tropical very wet forest, 560m), 1 male, 14-16.VII.1975, Malaise trap, R.C. Wilkerson leg. (FSCA, D. obliquus junior synonym). New material: MEXICO, Vera Cruz: Cordoba, 1 male, 4.IV.1974, W. Hanson \& G. Bohart leg. (EMUS); 5 males, 20.VII.1966, J.S. Bucket, M.R. \& R.C. Gardner leg. (UCDC); 1 male, 4.IX.1974, W. Hanson \& G. Bohart leg. (EMUS); 1 male, 1100 feet, Catemaco, 16-18.VI.1966, Malaise trap (CNCI); Chiapas: Yerba Buerra (5800'), 1 male, 18.VI.1969, Malaise trap, B.V. Peterson leg. (CNCI); (16 $\left.58^{\prime} \mathrm{N}, 91^{\circ} 47^{\prime} \mathrm{W}, 560 \mathrm{~m}, 28 . \mathrm{X} .1978\right), 1$ male, R. Rawlins leg. (CNCI); Yaxoquintelá (160 $\left.58^{\prime} \mathrm{N}, 91^{\circ} 47^{\prime} \mathrm{W}, 560 \mathrm{~m}\right), 1$ male, 6-9.XI.1978, J.E. Rawkins leg. (OSUC). HondURAs: Lago de Yojoa (600-650m), 1 male, VII.1981, N.L.H. Kraus leg. (AMNH). GuATEMALA: Zacapa (2 km N Santa Cruz), 8 males, XI.1986, Malaise trap, M. Sharkey leg. (PMAE). CosTA RiCA, San Vito de Coto Brues: Las Cruces, 4 males, 7.VIII-12.IX.1982, B. Gill leg. (CNCI, PMAE); Guanacaste: (3 km SE R. Naranjo), 2 males, 1-10.X.1992, F.D. Parker leg. (EMUS); Turrialba: 1 male, 9.VIII.1992, J. Maldonado C. leg. (USNM); Heredia: Est. Biol. La Selva, 1 male, 11-17.I.1986, W. Hanson \& G. Bohart leg. (EMUS); 2 males, 
22-26.VI.1993, Malaise trap, B. Brown \& D.H. Feerner leg. (LACM); San Jose: San Jose, 1 male, 22-23.XII.1987, F.D. Parker leg. (EMUS); (Pan-Am Hwy 14 rd miles N, San Isidro de General, ca 1600m), 1 male, W.A. Harding \& J.P. Donahue leg. (LACM); Escazu, 1 male, 8.II.1987, G.E. Bohart leg. (EMUS); (1100-1200m), 1 male, VIII.1980, N.L.H. Krauss leg. (AMNH). PANAMA, Canal Zone: Gamboa (Pipeline road), 1 male, VII.1967, Malaise trap, W.W. Wirth leg. (CNCI); Tabernilla, 1 male, A. Busck leg. (USNM). ECUADOR, Pichincha: Tinalandia (16 km SE Santo Domingos, 560m), 1 male, VI-VIII.198, S. \& J. Peck leg. (PMAE); Mor. Santiago: Miazal (50km SE Macas, 300m), 1 male, 4-7.I.1993, M. \& J. Wasbauer leg. (UCDC).

Variations. Texture weaker, with punctures less conspicuous, depression of the tergite II subcircular or more elliptical, or longer and distant each other $1.0 \mathrm{X}$ their length, or shorter and distant each other $1.7 \mathrm{X}$ their length; apex of the ventral ramus of Colombia specimen slightly more dilated.

Remarks. This species is recorded for the first time to Chiapas (Mexico) and Panama. An analysis of the genitalia and tergal modification has shown that $D$. obliquus to be junior synonym of $D$. rufipalpis.

Distribution. Mexico (Vera Cruz, Chiapas), Belize, Guatemala, Honduras, Costa Rica, Panama, Colombia and Ecuador.

\section{Dissomphalus xanthopus Ashmead, 1893}

Fig. 19

Diagnosis. Male: mandible tetradentate. Clypeus tridentate, high medially, with two carinae parallel basally and divergent apically, strongly angulate in profile before the apical margin, space between carinae with a shallow depression. Frons somewhat strongly coriarious, punctures large, shallow, separated by $1.5 \mathrm{X}$ their diameters. Vertex straight by a short distance, corners broadly rounded. Tergite II with a pair of lateral subcircular deep depressions, far from lateral margin and the anterior margin of tergite $0.33 \mathrm{X}$ their diameters, each one with hairy margins, latero-anterior margin densely hairy, with an anterior large pit carinate in the border, $0.5 \mathrm{X}$ the size of the depression, and with a hairy tuft, tergite sparse-haired behind. Hypopygium short, with a stalk $1.1 \mathrm{X}$ the length of hypopygium, lateral teeth 3.7 $\mathrm{X}$ smaller than the stalk, posterior margin slightly concave, with angulate corners.

Genitalia (Fig. 19). Paramere with oblique and concave apex, ventral and dorsal margins straight; aedeagus with ventral ramus large, but shorter than the dorsal body, slightly arched downward, wide, slightly wider medially, with a tooth-shaped apical projection slightly convergent, base of such projection serrated ventrally, inner margin serrated by a short distance apically and with a ventral filament slightly convergent, $0.5 \mathrm{X}$ longer than the own ramus; dorsal body of the aedeagus laminar, surfaces horizontal basally and medially, and arched downward laterally in the apex, dorsal body very wide, with a large rounded projection basal-medially, outer margin convergent apically, apex widened, rounded and with two teeth not so large and conspicuous, being the outer larger, with surfaces vertical and directed inward and the inner, more dorsal, smaller, with surfaces vertical and 
directed downward; basiparamere widened medially in the ventral side and very short basally; apodema extending beyond the elliptical genital ring.

Female. Head: weakly coriarious, nearly polish, punctures inconspicuous, very small, shallow, separated by $2-3 \mathrm{X}$ their diameters. Mandible tetradentate. Clypeus with a median carina very high and straight in profile, wide below, so that its transversal section is conical, extending to apical margin, and forming a right angle, apical margin with a median lobe very projected and subtrapezoidal. Eye circular, with four facetes, head with sides slightly convergent anteriorly, slightly convex. Vertex slightly concave, with rounded corners. Mesonotum with posterior margin slightly convex and embracing weakly by the propodeum. Propodeal disc with maximum width $1.12 \mathrm{X}$ the minimum, tibiae not spinose. Gaster peciolate.

Material examined. USA, Michigan: LivingTon County (Reserve, E.S. George), 1 female, 24.VI.1949, K. Bohnsack leg. (USNM), District of Columbia: Hamilton Hills (Washington), 1 female, 4.III.1925, H.S. Barber leg. (USNM); Kansas: Manhattan, 1 male, 29.VIII.1933, P.A. Wilbur, point c, (MCZH); Kentucky: East Cave, 1 male, H.E.M. Clare leg. (MCZH); Tennessee: Hamilton Co., 1 male, 20.IX.1939, 15266, lote 39-16383, Turner leg. (USNM); Texas: El Paso County (from peach soil), 1 female, 2.XI.1936 (USNM, paratype of Psilobethylus lucides); 1 male, 23.VII.1937, W.F. Turner \& W.H. Anderson leg. (USNM); Florida: Jackson County (Fla. Cave St. Pk., liter), 2 females, 9.IX.1968 and 09.IV.1969, S. Peck leg. (MCZH). MeXICO, Jalisco: (21 mi. NE, Tepatitlan), 1 male, 8.VIII.1960, P.H. Arnaud Jr., E.S. Ross \& D.C. Rentz leg. (CASC); Vera Cruz: Motzorongo, 1 male 11.II.1892, H. Osborn leg. (USNM). New material: USA, Pennsylvania: St. Vinc., 30 females, 9/8-95 (maybe $=9$.VIII.1895), Collection T. Pergande (USNM); Missouri: Columbia Boone County, 2 males, 23.IX.1967-30.IV.1968, Malaise trap, F.D. Parker leg. (USNM); Virginia: Fairfax County (near Annandale), 1 male 13.VIII.1981, Malaise trap, D.R. Smith leg. (USNM).

Variations. Males: body evenly castaneous, legs, mandible and antenna frequently castaneous; frons somewhat weakly coriarious, frontal carina well-defined, median carinae of the clypeus fused apically, frons with a linear depression in the posterior half between anterior ocellus and the frontal carina, head more developed behind the eyes, propodeal disc more weakly striate, or with one more pair of discal carinae, but poor-defined, anterior area of the pronotal disc strongly depressed, parapsidal furrows parallel with an outer carina, discal carinae poor-defined, notauli evenly wide, declivity of the propodeum wholly coriarious and without median carina, discoidal and subdiscoidal veins very weakly pigmented only at the beginning. Females: median tooth of the mandible sharpened, head with sides parallel, eye subcircular, vertex more concave medially.

Remarks. This species has some uncommon characters as: without striae in the metapleuron and lateral of the propodeum and clypeus bicarinate which makes promptly recognized.

Distribution. USA (Alabama, Arkansas, District of Columbia, Florida, Illinois, Louisiana, Kansas, Kentucky, Maryland, Michigan, Mississippi, Missouri, North Carolina, Tennessee, Texas, Virginia) and Mexico (Sonora, Jalisco, Vera Cruz, Tabasco, Chiapas). 


\section{Dissomphalus microtuberculatus sp.n.}

Fig. 20

Dissomphalus incomptus Evans, 1964 (partim).

Description. Male: length of body $3.07 \mathrm{~mm}$; LFW $2.32 \mathrm{~mm}$.

Color. Head and mesosoma black; gaster dark castaneous; clypeus dark castaneous; mandible castaneous; antenna castaneous with flagellomeres abruptly darker; palpi pale castaneous; leg castaneous; tibiae and tarsi lighter; wings hyaline.

Head. Mandible tridentate. Clypeus short and rounded. First four antennal segments in a ratio of 11:3.5:4:4.5; segment XI $2.2 \mathrm{X}$ as long as thick; sensilla slightly elongated. Frons coriarious, punctures shallow, not so large, separated by 0.5-1.5 X their diameters, frontal carina $0.46 \mathrm{X}$ length of clypeus. LH 1.0 X WH; WF 0.59 X WH; eye uncommonly large, WF 0.83 X HE; OOL 1.22 X WOT; DAO $0.38 \mathrm{X}$ WOT; posterior ocellus distant from the vertex crest $1.0 \mathrm{X}$ DAO. Vertex slightly convex, corners rounded. VOL $0.32 \mathrm{X} \mathrm{HE}$.

Mesosoma. Thorax coriarious, punctures small, shallow separated by 1-2 X their diameters. Pronotal disc $0.77 \mathrm{X}$ the length of mesoscutum. Propodeal disc 0.94 $\mathrm{X}$ as long as wide, with a complete median carina, wholly striate; declivity strongly striate. Metacarpo $1.33 \mathrm{X}$ the stigma. Forefemur $2.71 \mathrm{X}$ as long as thick.

Gaster. Transversal section elliptical. Tergite II with a pair of minute microtubercles, close to the anterior margin of the tergite, and placed in the median third of its width. Hypopygium with a slender stalk, 1.6 X the length of hypopygium, the lateral teeth $4 X$ shorter than the stalk, posterior margin slightly concave, corners rounded.

Genitalia (Fig. 20). Paramere short, $0.5 \mathrm{X}$ as long as the basiparamere, with wide, truncate and oblique apex, with dorsal corner produced and sharpened; aedeagus with ventral ramus conspicuous, as long as dorsal body, wide except the apex thin, with inner margin excavated, median portion of ramus broadly concave, outer margin wholly convex, apex slightly diverging, so that the ramus is sinuous; dorsal body very complex, with five pairs of apical lobes, the dorsal pair with a ventral surface laminar and vertical, rounded and wide in dorsal view, with an expansion in the side forming a lamina parallel, which seems a long tooth, this lamina perpendicular to the ventral one, and very angled upward medially, so that seems an independent lobe in dorsal view; the other lobe is lateral and conical; below this there are 2 pairs of cylindrical and smooth flagella, the dorsal nearly parallel and projected backward, and the ventral projected downward and diverging apically the ventral pair is stout, membranous and wholly covered by a membrane with rounded teeth, this as long the ventral pair of flagella; apodema not extending beyond the elliptical genital ring.

Material examined. ARGENTINA, Salta: Orán (Abra Grande), 8 males, 18.IV5.V.1969, E. Porter leg. (MCZH, holotype and paratypes); 1 male, 29.I-7.II.1967, R. Golbach leg. (FMIL, paratype of D. incomptus); Camp. Jakúlica (ca. Aguas Blancas), 2 males, X.1968, C. Porter leg. (MCZH, paratypes); Tucumán: Horco Molle, 2 males, XII.1968; C. Porter leg. (CNCI); 2 males, XII.1968, J. Foerter leg. 
(CNCI); San Xavier Mts., 4 males, 4-12.I.1966 and IV.1966, L. Stange leg. (FIML, paratypes of D. incomptus); 1 male, 10-23.XII.1967; C.C. Porter leg. (MCZH, paratype of $D$. incomptus); 1 male, XII.1968 (PMAE).

Variations. Head, mesosoma and mandible dark castaneous, gaster lighter or darker, antenna darkening gradually; punctures small; sides of the head slightly convergent below; frons slightly more or less coriarious; vertex with a small median depression; median tooth of the clypeus larger; vertex with corners broadly rounded; striae of the propodeum weaker; microtubercles of tergite II slightly more conspicuous or very inconspicuous; ventral ramus of the aedeagus longer than dorsal body; the parallel lamina of dorsal lobe of the aedeagus larger.

Remarks. There are two pattern of head profile in this species, one with vertex more rounded, temple divergent and front weakly coriarious, and another one with vertex hardly convex, temple barely divergent and frons coriarious. These patterns occur in Salta and Tucumán. This species is very similar to $D$. incomptus by the minute tubercles of tergite II of the gaster. But, there are some differences in the genitalia characters between them, as follow: in D. microtuberculatus sp.n. the apex of the ventral ramus of the aedeagus is acute, the flagella is smooth, lateral projection of dorsal body is not leaf-shaped and the third pair of apical lobe of dorsal body is larger.

Distribution. Argentina (Salta, Tucumán).

ACKNOWLEDGMENT. To E.R. Bortolini (UFES) for the loan of microscopy used to illustrate the genitalia; all curators for the loan the specimens recorded in the text and by the duplicates retained.

\section{REFERENCES}

AshmeAD, W.H. 1893. Monograph of the North American Proctotrypidae. Bull. U.S. Nat. Mus. 45: 1-472.

AzEVEDO, C.O. 1999. Revision of the Neotropical Dissomphalus Ashmead, 1893 (Hymenoptera, Bethylidae) with median tergal processes. Arqs Zool., São Paulo, 35 (4): 301-394.

Evans, H.E. 1962. Further studies on the genus Dissomphalus in the United States, Mexico, and Greater Antilles (Hymenoptera, Bethylidae). Proc. Entomol. Soc. Wash. 64 (2): 65-78.

. 1964. A synopsis of the American Bethylidae (Hymenoptera, Aculeata).

Bull. Mus. Comp. Zool. 132 (1): 1-222.

- 1966. Further studies on Neotropical Pristocerinae (Hymenoptera, Bethylidae). Acta Hymenopterologica 2 (3): 99-117.

-1969. The genera Apenesia and Dissomphalus in Argentina and Chile (Hymenoptera, Bethylidae). Breviora 311:1-23.

. 1979. The genus Dissomphalus in Northwestern South America

(Hymenoptera, Bethylidae). Proc. Entomol. Soc. Wash. 81 (2): 276-284.

GORDH, G. \& L. MOCZAR. 1990. A catalog of the world Bethylidae (Hymenoptera).

Mem. Amer. Entomol. Inst. 46: 1-364. 
HARRIS, R.A. 1979. A glossary of surface sculpturing. Occ. Pap. Entomol. 28 : $1-31$.

KIEFFER, J.J. 1910a. Description de nouveaux microhyménoptères du Brésil. Ann. Soc. Entomol. France 79: 31-56.

. 1910b. Description de nouveaux Béthylides (Hymenoptera). Ann. Soc. Entomol. France 79: 31-56.

1914. Bethylidae. Das Tierreich 41: 1-595.

Recebido em 07.V.1998; aceito em 27.VIII.1999. 